\title{
Biogeochemical modelling in the Bay of Seine (France): an improvement by introducing phosphorus in nutrient cycles
}

\author{
Jean-François Guillaud*, Françoise Andrieux and Alain Menesguen
}

IFREMER-Brest, Département Écologie Côtière, BP 70, 29280 Plouzané, France

*: Corresponding author : Fax +33 298224548 ; e-mail : guillaud@ifremer.fr

\begin{abstract}
:
As part of the French National Programme for Coastal Oceanography, this paper focuses on improvement of biogeochemical modelling in the Bay of Seine (Eastern Channel), by introducing phosphorus in nutrient cycles. The Bay of Seine receives the Seine river, which exhibits very high nutrient concentrations, and this coastal zone constitutes a typical case of eutrophication in a river plume area. In terms of analyses, sequential extraction and analysis of sedimentary phosphorus were used in order to measure various forms of particulate phosphorus in suspended matter and sediment (calcium-bound phosphate, Fe/Al-bound phosphate, exchangeable phosphate and organic phosphorus). In the modelling approach, the Bay is divided into 42 boxes and a two-layer, vertical thermohaline model is linked with the horizontal circulation scheme to take vertical stratification into account. The previous biological sub-model, with only nitrogen and silicon as nutrients, was improved by taking account of (a) various forms of bioavailable phosphorus (dissolved phosphate, exchangeable phosphate and organic phosphorus) and (b) experimental parameters which govern the adsorption/desorption of phosphate at the solid-water interface. The ecological model accurately reproduces dissolved nutrient behaviour in the river plume, and concentrations of diatoms, flagellates and zooplankton are consistent with observed values. Simulated exchangeable phosphate and organic phosphorus in suspended matter are in the range of measured concentrations, whereas these particulate variables are simulated with less accuracy in the sediment. After evaluating the respective roles of nitrogen, phosphorus and silicon as limiting factors for phytoplanktonic growth, the model was used to estimate consequences of reduced phosphorus or nitrogen input for phytoplanktonic production in the Bay of Seine.
\end{abstract}

Keywords: biological two-layer box model, river plume, phosphorus, phytoplankton, Bay of Seine. 


\section{Introduction}

Marine coastal eutrophication is a worldwide phenomenon and large phytoplanktonic blooms in the plumes of large rivers have been well documented for the northern Adriatic Sea (Justic, 1991), the North Sea (Peperzak et al., 1996 ; Radach, 1992), and the Baltic Sea (De Jonge et al., 1994). In France, the Bay of Seine, located in the eastern English Channel, can be considered as one of the most eutrophicated coastal ecosystems, due to large nutrient loadings from the Seine river (Aminot et al., 1997).

Mathematical modelling approaches were applied in order to quantify the respective roles of hydrodynamics and nutrient inputs in the coastal eutrophication process. The earliest models for the shelf area concerned the entire English Channel (Agoumi, 1985 ; Hoch, 1995), and the most recent dealt with the Bay of Seine (Ménesguen et al., 1995 ; Guillaud and Ménesguen, 1998). Results from the last model highlight the spatial concordance of the highest phytoplanktonic concentrations with the spread of the river plume in the Bay. Contrary to that of diatoms, flagellate production appears to be mainly confined to the eastern Bay, due to the vertical haline stratification just off the river mouth. These results for both phytoplankton groups confirm that vertical structure modelling is necessary to simulate the biological consequences of fresh water spreading in the Bay. Previous models for the Bay dealt only with nitrogen and silicon cycles. They did not include phosphorus and its potentially limiting effect seeing the recent decrease in loading by the river Seine (Aminot et al., 1997). Thus, this study aimed to improve simulation of primary production of the Bay of Seine, by incorporating measurements of various forms of phosphorus, and their cycles into the previous model. However, the phosphorus cycle differs significantly from nitrogen and silicon cycles since it exhibits a multiple particulate phase. More sophisticated processes, like adsorption and desorption, must be included in the model, according to Chapelle (1995), Furumai et al. (1989).

\section{Material and methods}

\subsection{Study site}

The Bay of Seine is located in north-western France and opens onto the English Channel along its northern boundary (Fig. 1). The surface area of the Bay is $5000 \mathrm{~km}^{2}$, its mean depth is about $15 \mathrm{~m}$ and the tidal range reaches $7 \mathrm{~m}$. Fine to very fine sands are found towards the Seine's mouth, with several muddy zones. In the Bay's central and western zones, sediments are almost all gravel and gravelly coarse sand. Although seasonal differences in wind and river inflow alter water-mass movements in the Bay, the basic flow patterns are tidally induced. The Seine river flows into the bay with a mean discharge of $450 \mathrm{~m}^{3} / \mathrm{s}$. The river flow can reach $2000 \mathrm{~m}^{3} / \mathrm{s}$ during floods, dropping to $100 \mathrm{~m}^{3} / \mathrm{s}$ at low water. The yearly mean loads of dissolved inorganic nitrogen, dissolved silicate, dissolved phosphate and particulate phosphorus from the Seine river are respectively $80000 \mathrm{t}, 46000 \mathrm{t}, 8400 \mathrm{t}$ and $2600 \mathrm{t}$ (Aminot et al., 1993 ; Menesguen et al., 1995). Other rivers (Orne, Douve, Vire) flowing into the Bay respectively present total nitrogen and phosphorus loads of about $10 \%$ and $2 \%$ of the Seine river loads (Cugier, 1999).

These inputs induce high primary production during spring and summer in the river plume, and every year chlorophyll $a$ concentrations reach values between 30 and $70 \mu \mathrm{g} / \mathrm{dm}^{3}$ (Aminot et al., 1997). Diatoms are dominant, but flagellates can become abundant in late summer, with Dinophysis sp. blooms reaching $10^{6}$ cells $/ \mathrm{dm}^{3}$ (Le Grand, 1994).

\subsection{Measurement procedures}

Nutrient and chlorophyll $a$ measurements at station 2 ("RNO 2" on Figure 1), used in this study, were performed by the R.N.O. (French National Monitoring Network for Marine Environment Quality) from 1976 to 1984 (R.N.O., 1976-1984). Unfortunately the R.N.O. sampling strategy was changed in 1985, and high frequency measurements have not been performed at fixed stations since then. Specific measurements of particulate compounds of phosphorus in the Bay have been performed since 1992 within the framework of the Bay of Seine project, as part of French National Programme for Coastal Oceanography (Andrieux-Loyer, 1997). Annual maximum concentrations of flagellates have been provided since 1983 along the Bay of Seine coast by the French National Phytoplankton and Phycotoxins Monitoring Network (Belin and Raffin, 1998).

Ammonium, nitrate, phosphate and silicate were determined using methods described by Strickland and Parsons (1972) ; precision for nutrients is about 5-10\%. Chlorophyll $a$ in the water column was 
measured using Lorenzen's fluorimetric method (1966), accurate to $\pm 0.1 \mu \mathrm{g} \mathrm{dm}{ }^{-3}$.

Sequential extraction and analysis of sedimentary phosphorus have been described in detail in Andrieux and Aminot (1997). Main features include measurement of total sedimentary and particulate phosphorus after ashing at $500{ }^{\circ} \mathrm{C}$, according to Rao and Reddi (1990). Major reservoirs of sedimentary P were determined using the widely used sequential method of Williams et al. (1976), as modified by Psenner et al. (1988) : (1) the non-apatite inorganic phosphate (NAIP) fraction which represents $\mathrm{Fe}$ - and $\mathrm{Al}-\mathrm{bound} \mathrm{P}(\mathrm{Fe} / \mathrm{Al}-\mathrm{P})$, and loosely sorbed so-called exchangeable phosphate (exch$\mathrm{P})$; (2) the calcium-bound-phosphate (Ca-P) fraction ; and (3) the organic phosphorus fraction (orgaP) calculated by difference (TP minus NAIP and Ca-P). In addition, exchangeable phosphate was determined using the Infinite Dilution Extrapolation method (Aminot and Andrieux, 1996). Duplicate total phosphorus analyses were made on 40 sediment samples. The standard deviation was $0.43 \mu \mathrm{mol} \mathrm{g}^{-1}$ on concentrations ranging from 8 to $22 \mu \mathrm{mol} \mathrm{g}^{-1}$. For sedimentary phosphorus forms, duplicate analyses were performed on 70 samples. The standard deviation was $0.1 \mu \mathrm{mol} \mathrm{g}^{-1}$ on $\mathrm{Fe} / \mathrm{Al}-\mathrm{P}$ concentrations of $0.1-9 \mu \mathrm{mol} \mathrm{g}^{-1}$, and $0.6 \mu \mathrm{mol} \mathrm{g}^{-1}$ on Ca-P concentrations of $4-12 \mu \mathrm{mol} \mathrm{g}{ }^{-1}$. The orga-P concentrations (40 samples : 2.8 to $7.8 \mu \mathrm{mol} \mathrm{g}^{-1}$ ), being calculated by difference, showed a slightly higher standard deviation equal to $1 \mu \mathrm{mol} \mathrm{g}$. For exch-P concentrations $\left(0.2-2.7 \mu \mathrm{mol} \mathrm{g}{ }^{-1}\right)$, the Infinite Dilution Extrapolation method consisted of 7 extractions for each value, and the resulting standard deviation was 0.02 to $0.1 \mu \mathrm{mol} \mathrm{g}{ }^{-1}$.

According to Andrieux and Aminot (1997), in our modelling approach we considered only exchangeable phosphate and organic phosphorus as being potentially bioavailable in the Bay of Seine ; these forms represent about $50 \%$ of the total particulate phosphorus load from the Seine river (Aminot et al., 1993). Calcium-bound phosphate and Fe/Al-bound phosphate are not taken into account by the model because they represent insoluble and non-reactive forms under the physicochemical conditions of Bay waters.

\subsection{Mathematical model description}

The basic model used in this study has been fully described by Guillaud and Ménesguen (1998). It was implemented using IFREMER's "ELISE" software (Ménesguen, 1991) which allows results of a hydrodynamic model to be combined with biogeochemical equations.

\section{Hydrodynamic sub-model}

In this sub-model, the Bay of Seine is divided into 42 boxes (Fig. 1) and water fluxes between them are calculated automatically by "ELISE" software, using the horizontal 2D-lagrangian residual currents computed by Salomon and Breton (1991). In order to take account of thermal and haline stratifications, a two-layer vertical thermohaline model is linked with the horizontal circulation scheme (Ménesguen and Hoch, 1997), and each box is divided into a surface and a bottom box, with a moving frontier in the pycnocline region. In stratified areas, this model cannot simulate potential dense accumulations of phytoplankton in the pycnocline zone located between the surface and the bottom layer (Videau et al., 1998). Nevertheless, in spite of its roughness, the two layer biogeochemical boxmodel, with a time-varying thermohalocline, is powerful enough to simulate vertical structure in much less computing time than for real three-dimensional modelling, particularly in case of simulations over a period of twenty years.

Finally sediment boxes were added under the water boxes to study state variables in the sediment ; exchanges between water and sediment are linked to diffusion for dissolved variables. For particulate variables, exchanges are related to settling velocity, and to the ratio of shear stress $(\tau)$ to critical shear stress $\left(\tau_{\mathrm{cd}}\right)$ for deposition, or to critical shear stress $\left(\tau_{\mathrm{ce}}\right)$ for erosion. The shear stress on the bottom is generated by tidal current and wave action (Soulsby et al., 1993).

\section{Biological sub-model}

Starting with the preliminary nitrogen and silicon model of Guillaud and Ménesguen (1998), a model of combined nitrogen, silicon and phosphorus cycles was set up in order to investigate the role of phosphorus as a potential limiting nutrient in the Bay of Seine. The following 11 state variables were selected :

$\mathrm{X}_{1}$ : nitrate 
$\mathrm{X}_{2}$ : ammonium

$\mathrm{X}_{3}$ : dissolved silicon

$\mathrm{X}_{4}$ : dissolved phosphate

$\mathrm{X}_{5}$ : particulate exchangeable phosphate

$\mathrm{X}_{6}:$ diatom nitrogen

$\mathrm{X}_{7}$ : flagellate nitrogen

$\mathrm{X}_{8}$ : zooplankton nitrogen

$\mathrm{X}_{9}$ : detrital organic nitrogen

$\mathrm{X}_{10}$ : detrital biogenic silicon

$\mathrm{X}_{11}$ : detrital organic phosphorus

The model also simulates three independent biotope descriptors : salinity $\left(\mathrm{X}_{\text {sal }}\right)$, temperature $\left(\mathrm{X}_{\text {temp }}\right)$, and inorganic suspended matter $\left(\mathrm{X}_{\mathrm{sm}}\right)$. The first is a pure conservative tracer and the last is required to calculate the light extinction coefficient and particulate exchangeable phosphate.

Two distinct groups of phytoplankton are simulated: (1) diatoms, which are the main primary producers in the English Channel, and are nitrogen-, phosphorus- and silicon-dependent, and (2) flagellates, including some harmful species, which do not require silicon. According to Aksnes et al. (1995), Le Pape (1996) and Varela et al. (1995), who successfully differentiated diatoms and flagellates in their modelling approach, the model considers only these two phytoplanktonic groups in order to reconcile moderate modelling complexity with realistic simulations of main primary producers. Nanophytoplankton is not taken into account because of its limited role in primary production in the English Channel, pointed out by Hoch (1998). As the aim of this model is to simulate seasonal variations of microalgae, the transitory buffering effect of internal nutrient storage was considered as negligible on a seasonal scale ; so nutrient uptake and phytoplanktonic growth are directly linked.

Phytoplankton's potential growth rate is stimulated by temperature (Eppley, 1972), according to an exponential law $\left(\mathrm{Q}_{10}=2\right)$ with no inhibitory effect of temperature in the range of $0-25 \mathrm{C}^{\circ}$. Growth limitation by each nutrient follows a Michaelis-Menten kinetic, and a Steele's function (Steele, 1962) describes how light controls the growth rate; Liebig's minimum law related to limiting effects of nitrogen, phosphorus, silicon (for diatoms only) and light is used to modulate the growth rate. The light extinction coefficient is calculated by means of a correlation with total suspended matter concentrations (Ménesguen et al. 1995), and phytoplanktonic self-shading is taken into account by adding a dry mass of phytoplankton to inorganic suspended matter. Phytoplankton mortality is related to temperature, and the sedimentation rate of diatoms increases when their nutrient limitation increases (Titman and Kilham, 1976). Flagellates are assumed not to settle because of their own motility.

Grazing pressure is represented by zooplankton, but the grazing of flagellates is not taken into account, due to zooplankton's ability to avoid dinoflagellates, pointed out by Ives (1987) ; Hoch (1998), considers that only $10 \%$ of flagellates are grazed by zooplankton. Zooplankton's growth rate depends on temperature and the diatom biomass, following Ivlev's formula, modified by Hoch (1995). Zooplankton excretion is a function of temperature, as is their mortality which also depends on the zooplanktonic biomass, reflecting the predation concomitant to the increase in biomass (Steele and Henderson, 1992).

Biogenic detrital silicon dissolution, and organic nitrogen and organic phosphorus mineralisation are temperature-dependent (Arrhenius' law). These processes supply dissolved silicon, phosphate and ammonium, the last compound producing nitrate through nitrification.

The phosphorus simulation takes the exchange between dissolved phosphate and particulate exchangeable phosphate in suspended matter or sediment, through adsorption and desorption processes into account. According to Furumai et al. (1989) and Andrieux-Loyer (1997), the adsorption kinetics are proportional to the dissolved phosphate concentration, and to the difference between maximum phosphate adsorption capacity of particulate matter and its instantaneous exchangeable phosphate concentration; the kinetics of desorption are proportional to the exchangeable phosphate concentration in particulate matter, and modulated by the ratio of this exchangeable phosphate concentration to the maximum phosphate adsorption capacity of particulate matter.

The conceptual biological model of phosphorus cycling is described in Figure 2. For other nutrients (N and $\mathrm{Si}$ ) the diagram is the same, excepting phosphorus-specific processes (adsorption/desorption). 
Obviously, there is no silicate uptake by flagellates.

To express differential equations representing the evolution of state variables over time, the following expressions are used :

- Action of temperature $\mathrm{T}\left({ }^{\circ} \mathrm{C}\right): \mathrm{f}_{\mathrm{T}}=\exp \left(\mathrm{k}_{\mathrm{T}} \cdot \mathrm{T}\right)$ with $\mathrm{k}_{\mathrm{t}}=0.07^{\circ} \mathrm{C}^{-1}$ (Eppley, 1972)

- Action of nutrient limitation (N, Si, P) on phytoplankton growth (Michaelis' formulation) :

*for diatoms: $\quad \mathrm{f}_{\text {Ndiat }}=\frac{\mathrm{X}_{1}+\mathrm{X}_{2}}{\mathrm{X}_{1}+\mathrm{X}_{2}+\mathrm{k}_{\text {Ndiat }}} \quad, \mathrm{f}_{\text {Sidiat }}=\frac{\mathrm{X}_{3}}{\mathrm{X}_{3}+\mathrm{k}_{\text {Sidiat }}} \quad$ and $\mathrm{f}_{\text {Pdiat }}=\frac{\mathrm{X}_{4}}{\mathrm{X}_{4}+\mathrm{k}_{\text {Pdiat }}}$

*for flagellates: $\quad \mathrm{f}_{\text {Nflag }}=\frac{\mathrm{X}_{1}+\mathrm{X}_{2}}{\mathrm{X}_{1}+\mathrm{X}_{2}+\mathrm{k}_{\text {Nflag }}}$ and $\mathrm{f}_{\text {Pflag }}=\frac{\mathrm{X}_{4}}{\mathrm{X}_{4}+\mathrm{k}_{\text {Pflag }}}$

- Action of light on phytoplankton growth (Steele's formulation) :

$\mathrm{f}_{\mathrm{L}}=\iint\left(\frac{\mathrm{I}_{\mathrm{z}, \mathrm{t}}}{\mathrm{I}_{\mathrm{sat}}}\right) \cdot \exp \left(1-\frac{\mathrm{I}_{\mathrm{z}, \mathrm{t}}}{\mathrm{I}_{\mathrm{sat}}}\right) \cdot \mathrm{dz} \cdot \mathrm{dt}$

with $I_{\text {sat }}=I_{\text {satdiat }}$ for diatoms, and $I_{\text {sat }}=I_{\text {satflag }}$ for flagellates

and light intensity at depth $\mathrm{z}: \mathrm{I}_{\mathrm{z}, \mathrm{t}}=\mathrm{I}_{0, \mathrm{t}} \cdot \exp \left(-\mathrm{kL}_{\mathrm{L}} \cdot \mathrm{z}\right)$

- Action of nutrient limitation on diatom settling velocity :

$\mathrm{v}_{\text {sdiat }}=\mathrm{v}_{\text {sdiatmin }} \cdot$ nutstat $_{\text {diat }}+\mathrm{v}_{\text {sdiatmax }} \cdot\left(1-\right.$ nutstat $\left._{\text {diat }}\right)$

with nutstat ${ }_{\text {diat }}$ as nutrient status index depending on nutrient limitation :

nutstat $_{\text {diat }}=\left[\min \left(\mathrm{f}_{\text {Ndiat }}, \mathrm{f}_{\text {Sidiat }}, \mathrm{f}_{\text {Pdiat }}\right)\right]^{\frac{1}{5}}$

- Box depth is labelled h, and bottom is a Boolean indicator which equals 1 if the box is in contact with the sediment (equal to 0 elsewhere).

Finally, the differential equations representing the evolution of the 11 state variables over time can be expressed as follows (for basic parameters, see table 1) :

Nitrate :

$$
\begin{aligned}
\frac{\mathrm{dX}_{1}}{\mathrm{dt}} & =\mathrm{k}_{\text {nitrif }} \cdot \mathrm{f}_{\mathrm{T}} \cdot \mathrm{X}_{2}-\mu_{\text {max diat }} \cdot \mathrm{r}_{\mathrm{NO} 3} \cdot \mathrm{f}_{\mathrm{T}} \cdot \min \left(\mathrm{f}_{\text {Ndiat }}, \mathrm{f}_{\text {Sidiat }}, \mathrm{f}_{\text {Pdiat }}, \mathrm{f}_{\text {Ldiat }}\right) \cdot \mathrm{X}_{6} \\
& -\mu_{\text {max flag }} \cdot \mathrm{r}_{\mathrm{NO} 3} \cdot \mathrm{f}_{\mathrm{T}} \cdot \min \left(\mathrm{f}_{\text {Nflag }}, \mathrm{f}_{\text {Pflag }}, \mathrm{f}_{\text {Lflag }}\right) \cdot \mathrm{X}_{7}
\end{aligned}
$$

with $\mathrm{r}_{\mathrm{NO} 3}=\frac{\mathrm{X}_{1}}{\mathrm{X}_{1}+\mathrm{X}_{2}}$

Ammonium :

$$
\begin{aligned}
& \begin{aligned}
\frac{\mathrm{dX}_{2}}{\mathrm{dt}} & =\mathrm{k}_{\mathrm{Nmin}} \cdot \mathrm{f}_{\mathrm{T}} \cdot \mathrm{X}_{9}-\mu_{\max d i a t} \cdot \mathrm{r}_{\mathrm{NH} 4} \cdot \mathrm{f}_{\mathrm{T}} \cdot \min \left(\mathrm{f}_{\mathrm{Ndiat}}, \mathrm{f}_{\text {Sidiat }}, \mathrm{f}_{\text {Pdiat }}, \mathrm{f}_{\text {Ldiat }}\right) \cdot \mathrm{X}_{6} \\
& -\mu_{\text {max flag }} \cdot \mathrm{r}_{\mathrm{NH} 4} \cdot \mathrm{f}_{\mathrm{T}} \cdot \min \left(\mathrm{f}_{\mathrm{Nflag}}, \mathrm{f}_{\text {Pflag }}, \mathrm{f}_{\mathrm{Lflag}}\right) \cdot \mathrm{X}_{7}+\mathrm{excr}_{\mathrm{zoo}} \cdot \mathrm{r}_{\mathrm{N} / \mathrm{dw}} \cdot \mathrm{f}_{\mathrm{T}} \cdot \mathrm{X}_{8}
\end{aligned} \\
& \text { with } \mathrm{r}_{\mathrm{NH} 4}=\frac{\mathrm{X}_{2}}{\mathrm{X}_{1}+\mathrm{X}_{2}}
\end{aligned}
$$

Dissolved silicon :

$$
\frac{\mathrm{dX}_{3}}{\mathrm{dt}}=\mathrm{k}_{\text {diss }} \cdot \mathrm{f}_{\mathrm{T}} \cdot \mathrm{X}_{10}-\mathrm{r}_{\mathrm{Si} / \mathrm{N}} \cdot \mu_{\text {max diat }} \cdot \mathrm{f}_{\mathrm{T}} \cdot \min \left(\mathrm{f}_{\text {Ndiat }}, \mathrm{f}_{\text {Sidiat }}, \mathrm{f}_{\text {Pdiat }}, \mathrm{f}_{\text {Ldiat }}\right) \cdot \mathrm{X}_{6}
$$


Dissolved phosphate :

$$
\begin{aligned}
\frac{\mathrm{dX}_{4}}{\mathrm{dt}} & =\mathrm{k}_{\mathrm{Pmin}} \cdot \mathrm{f}_{\mathrm{T}} \cdot \mathrm{X}_{11}+\mathrm{k}_{\text {desorp }} \cdot\left(\mathrm{X}_{5} /\left(\mathrm{Q}_{0 \operatorname{maxSM}} \cdot \mathrm{X}_{\mathrm{sm}}\right)\right) \cdot \mathrm{X}_{5}-\mathrm{k}_{\text {adsorp }} \cdot\left(\left(\mathrm{Q}_{0 \operatorname{maxSM}} \cdot \mathrm{X}_{\mathrm{sm}}\right)-\mathrm{X}_{5}\right) \cdot \mathrm{X}_{4} \\
& -\mu_{\text {max diat }} \cdot \mathrm{r}_{\mathrm{P} / \mathrm{N}} \cdot \mathrm{f}_{\mathrm{T}} \cdot \min \left(\mathrm{f}_{\text {Ndiat }}, \mathrm{f}_{\text {Sidiat }}, \mathrm{f}_{\text {Pdiat }}, \mathrm{f}_{\text {Ldiat }}\right) \cdot \mathrm{X}_{6} \\
& -\mu_{\max f l a g} \cdot \mathrm{r}_{\mathrm{P} / \mathrm{N}} \cdot \mathrm{f}_{\mathrm{T}} \cdot \min \left(\mathrm{f}_{\mathrm{Nflag}}, \mathrm{f}_{\mathrm{Pflag}}, \mathrm{f}_{\text {Lflag }}\right) \cdot \mathrm{X}_{7} \\
& +\operatorname{excr}_{\text {zoo }} \cdot \mathrm{r}_{\mathrm{P} / \mathrm{N}} \cdot \mathrm{r}_{\mathrm{N} / \mathrm{dw}} \cdot \mathrm{f}_{\mathrm{T}} \cdot \mathrm{X}_{8}
\end{aligned}
$$

Particulate exchangeable phosphate :

$$
\begin{aligned}
\frac{\mathrm{dX}_{5}}{\mathrm{dt}}= & -\mathrm{k}_{\text {desorp }} \cdot\left(\mathrm{X}_{5} /\left(\mathrm{Q}_{0 \operatorname{maxSM}} \cdot \mathrm{X}_{\mathrm{sm}}\right)\right) \cdot \mathrm{X}_{5}+\mathrm{k}_{\text {adsorp }} \cdot\left(\left(\mathrm{Q}_{0 \operatorname{maxSM}} \cdot \mathrm{X}_{\mathrm{sm}}\right)-\mathrm{X}_{5}\right) \cdot \mathrm{X}_{4} \\
& +\frac{\mathrm{v}_{\mathrm{sSM}}}{\mathrm{h}} \cdot\left(1+\text { bottom } \cdot\left(\operatorname{Sup}\left[0,1-\tau / \tau_{\mathrm{cd}}\right]-1\right)\right) \cdot \mathrm{X}_{5}
\end{aligned}
$$

Diatom nitrogen :

$$
\begin{aligned}
\frac{\mathrm{dX}_{6}}{\mathrm{dt}} & =\mu_{\text {max diat }} \cdot \mathrm{f}_{\mathrm{T}} \cdot \min \left(\mathrm{f}_{\text {Ndiat }}, \mathrm{f}_{\text {Sidiat }}, \mathrm{f}_{\text {Pdiat }}, \mathrm{f}_{\text {Ldiat }}\right) \cdot \mathrm{X}_{6}-m_{\text {diat }} \cdot \mathrm{f}_{\mathrm{T}} \cdot \mathrm{X}_{6} \\
& -\mu_{\text {max zoo }} \cdot \mathrm{f}_{\mathrm{T}} \cdot\left[1-\exp \left(-I v \cdot\left(\mathrm{X}_{6} / \mathrm{r}_{\mathrm{N} / \text { chloro }}-\mathrm{Pr}_{\text {th }}\right)\right)\right] \cdot \mathrm{r}_{\mathrm{N} / \mathrm{dw}} \cdot \mathrm{X}_{8} \\
& -\frac{\mathrm{v}_{\text {sdiat }}}{\mathrm{h}} \cdot\left(1+\text { bottom } \cdot\left(\operatorname{Sup}\left[0,1-\tau / \tau_{\mathrm{cd}}\right]-1\right)\right) \cdot \mathrm{X}_{6}
\end{aligned}
$$

Flagellate nitrogen :

$$
\frac{\mathrm{dX}_{7}}{\mathrm{dt}}=\mu_{\max f l a g} \cdot \mathrm{f}_{\mathrm{T}} \cdot \min \left(\mathrm{f}_{\text {Nflag }}, \mathrm{f}_{\text {Pflag }}, \mathrm{f}_{\mathrm{Lflag}}\right) \cdot \mathrm{X}_{7}-m_{\text {flag }} \cdot \mathrm{f}_{\mathrm{T}} \cdot \mathrm{X}_{7}
$$

Zooplankton biomass :

$$
\begin{aligned}
\frac{\mathrm{dX}_{8}}{\mathrm{dt}}= & \mu_{\operatorname{maxzoo}} \cdot \text { Ass } \cdot \mathrm{f}_{\mathrm{T}} \cdot\left[1-\exp \left(-I V \cdot\left(\mathrm{X}_{6} / \mathrm{r}_{\mathrm{N} / \text { chloro }}-\mathrm{Pr}_{\text {th }}\right)\right)\right] \cdot \mathrm{X}_{8} \\
& -\operatorname{excr}_{\text {zoo }} \cdot \mathrm{f}_{\mathrm{T}} \cdot \mathrm{X}_{8}-\max \left(m_{\operatorname{minzoo}}, m_{\mathrm{fzoo}} \cdot \mathrm{X}_{8}\right) \cdot \mathrm{f}_{\mathrm{T}} \cdot \mathrm{X}_{8}
\end{aligned}
$$

Detrital organic nitrogen :

$$
\begin{aligned}
\frac{\mathrm{dX}_{9}}{\mathrm{dt}} & =-\mathrm{k}_{\mathrm{Nmin}} \cdot \mathrm{f}_{\mathrm{T}} \cdot \mathrm{X}_{9}+\mathrm{f}_{\mathrm{T}} \cdot\left(m_{\text {diat }} \cdot \mathrm{X}_{6}+m_{\mathrm{flag}} \cdot \mathrm{X}_{7}\right) \\
& +\mathrm{f}_{\mathrm{T}} \cdot \max \left(m_{\operatorname{minzoo}}, m_{\mathrm{fzoo}} \cdot \mathrm{X}_{8}\right) \cdot \mathrm{r}_{\mathrm{N} / \mathrm{dw}} \cdot \mathrm{X}_{8} \\
& +(1-\mathrm{Ass}) \cdot \mu_{\max z o o} \cdot \mathrm{f}_{\mathrm{T}} \cdot\left[1-\exp \left(-I v \cdot\left(\mathrm{X}_{6} / \mathrm{r}_{\mathrm{N} / \text { chloro }}-\mathrm{Pr}_{\text {th }}\right)\right)\right] \cdot \mathrm{r}_{\mathrm{N} / \mathrm{dw}} \cdot \mathrm{X}_{8} \\
& +\frac{\mathrm{V}_{\mathrm{sPOM}}}{\mathrm{h}} \cdot\left(1+\text { bottom } \cdot\left(\operatorname{Sup}\left[0,1-\tau / \tau_{\mathrm{cd}}\right]-1\right)\right) \cdot \mathrm{X}_{9}
\end{aligned}
$$

Detrital biogenic silicon :

$$
\begin{aligned}
\frac{\mathrm{dX}_{10}}{\mathrm{dt}}= & -\mathrm{k}_{\mathrm{diss}} \cdot \mathrm{f}_{\mathrm{T}} \cdot \mathrm{X}_{10}+\mathrm{r}_{\mathrm{Si} / \mathrm{N}} \cdot \mathrm{f}_{\mathrm{T}} \cdot\left(m_{\text {diat }} \cdot \mathrm{X}_{6}+m_{\text {flag }} \cdot \mathrm{X}_{7}\right) \\
& +\mu_{\text {max zoo }} \cdot \mathrm{f}_{\mathrm{T}} \cdot\left[1-\exp \left(-I v \cdot\left(\mathrm{X}_{6} / \mathrm{r}_{\mathrm{N} / \text { chloro }}-\mathrm{Pr}_{\text {th }}\right)\right)\right] \cdot \mathrm{r}_{\mathrm{Si} / \mathrm{N}} \cdot \mathrm{r}_{\mathrm{N} / \mathrm{dw}} \cdot \mathrm{X}_{8} \\
& +\frac{\mathrm{V}_{\mathrm{sPOM}}}{\mathrm{h}} \cdot\left(1+\text { bottom } \cdot\left(\operatorname{Sup}\left[0,1-\tau / \tau_{\mathrm{cd}}\right]-1\right)\right) \cdot \mathrm{X}_{10}
\end{aligned}
$$


Detrital organic phosphorus :

$$
\begin{aligned}
\frac{\mathrm{dX}_{11}}{\mathrm{dt}} & =-\mathrm{k}_{\mathrm{Pmin}} \cdot \mathrm{f}_{\mathrm{T}} \cdot \mathrm{X}_{11}+\mathrm{r}_{\mathrm{P} / \mathrm{N}} \cdot \mathrm{f}_{\mathrm{T}} \cdot\left(m_{\text {diat }} \cdot \mathrm{X}_{6}+m_{\mathrm{flag}} \cdot \mathrm{X}_{7}\right) \\
& +\mathrm{f}_{\mathrm{T}} \cdot \max \left(m_{\operatorname{minzoo}}, m_{\mathrm{fzoo}} \cdot \mathrm{X}_{8}\right) \cdot \mathrm{r}_{\mathrm{P} / \mathrm{N}} \cdot \mathrm{r}_{\mathrm{N} / \mathrm{dw}} \cdot \mathrm{X}_{8} \\
& +(1-\mathrm{Ass}) \cdot \mu_{\max z o o} \cdot \mathrm{f}_{\mathrm{T}} \cdot\left[1-\exp \left(-I V \cdot\left(\mathrm{X}_{6} / \mathrm{r}_{\mathrm{N} / \text { chloro }}-\mathrm{Pr}_{\text {th }}\right)\right)\right] \cdot \mathrm{r}_{\mathrm{P} / \mathrm{N}} \cdot \mathrm{r}_{\mathrm{N} / \mathrm{dw}} \cdot \mathrm{X}_{8} \\
& +\frac{\mathrm{v}_{\mathrm{sPOM}}}{\mathrm{h}} \cdot\left(1+\text { bottom } \cdot\left(\operatorname{Sup}\left[0,1-\tau / \tau_{\mathrm{cd}}\right]-1\right)\right) \cdot \mathrm{X}_{11}
\end{aligned}
$$

For sediment boxes, the equations are similar, but do not integrate flagellates and zooplankton. The main processes taken into account are diatom mortality, organic material mineralisation and phosphate adsorption/desorption. Sediment density was equal to $2600 \mathrm{~kg} / \mathrm{m}^{3}$ and its consolidation not taken into account.

\section{Boundary conditions and driving variables}

As for the previous model, state variable values on the seaward boundary were provided by measurements performed in the English Channel by Bentley and Maillard-Quisthoudt (1990), Le Fèvre-Lehoërff et al. (1993), Tappin (1988), C.N.E.X.O. (1980) and I.O.S. (1987). Landward boundary conditions were provided by the Cellule Antipollution de la Seine (1976-1995) for the Seine river, and by Direction Régionale de l'Environnement and Agence de l'Eau Seine-Normandie for other smaller rivers (Orne, Vire and Douve).

Meteorological forcing was based on daily average measurements of driving variables (insolation duration, wind speed, air temperature, air moisture, atmospheric pressure and cloud cover) at the La Hague weather station (northwest cape of Cotentin) ; these day by day data were provided by MeteoFrance from 1976 to 1995.

\section{Results}

After improving the calibration of the previous model by taking account of dissolved phosphate measurements, the model was validated by comparing observed and calculated values of dissolved nutrients (N, Si, P), chlorophyll $a$, flagellates, zooplankton biomass and particulate forms of phosphorus. Finally the model was used to estimate nutrient limiting effects on phytoplankton growth in the plume area and in the Bay of Seine.

\subsection{Dissolved nutrients and chlorophyll a}

The data available at station 2 of the French National Monitoring Network ("RNO 2" in Figure 1) were compared with model results in box No 3, over the period of 1976-1984 (RNO, 1976-1984). Figure 3 illustrates the comparison, in surface water, between computed and observed values of dissolved inorganic nitrogen (nitrate plus ammonium), silicate, phosphate and chlorophyll $a$, which is calculated from diatom nitrogen divided by N/chlorophyll $a$ ratio (Jorgensen, 1979). Large seasonal variations for dissolved inorganic nitrogen and silicate can be observed, due to phytoplankton uptake and decreased river input during summer. Compared with nitrogen or silicate, phosphate concentrations fluctuate less because phosphate river inputs are constant during the year. This pattern is due to the prevalence of phosphate point sources in the river Seine, such as urban and industrial wastewater discharges (Menesguen et al., 1995). The model reproduces annual spring and summer blooms of chlorophyll $a$; nevertheless, some of the highest values are not reached by the model.

As in Andersen and Nival (1989) and Aksnes et al. (1995), general standard deviations C between simulated and observed values were calculated as follows :

$\mathrm{C}=\left[\sum_{i=1}^{n}\left(x_{c}-x_{o}\right)^{2}\right]^{1 / 2} / n x_{m} \quad$ where $x_{c}$ is the simulated value, $x_{o}$ the observed data, $x_{m}$ the mean of $x_{o}$ and $n$ the number of pairs of values compared. Values of $\mathrm{C}$ for dissolved inorganic nitrogen, silicate, phosphate and chlorophyll $a$ are respectively equal to $0.041,0.042,0.042$ and 0.068 . These values indicate better predictions for nutrients than for chlorophyll $a$, and according to $\mathrm{C}$ values found 
by Aksnes et al. (1995) in a similar modelling approach, their range indicates a good fit by the model. Furthermore, introducing phosphorus improves the model, because standard deviation values are equal for silicate, or lower for nitrogen and chlorophyll $a$ than those from the previous model. Indeed, previous $C$ values were respectively equal to 0.05 and 0.08 for nitrogen and chlorophyll $a$ (Guillaud and Ménesguen, 1998).

From a spatial point of view, the comparison between measured and calculated concentrations of chlorophyll $a$ in the Bay in June 1992 shows a relatively good fit, and highlights the increase in the chlorophyll $a$ gradient from offshore waters towards the estuary (Fig. 4).

\subsection{Flagellates}

Available measurements of yearly maximum dinoflagellate concentrations along the southern coast of the Seine mouth (Belin and Raffin, 1998) were compared with maximum simulated concentrations of flagellates in the plume (Fig. 5). For this comparison, number of dinoflagellates per $\mathrm{dm}^{3}$ was converted into $\mu \mathrm{mol}$ of nitrogen per $\mathrm{dm}^{3}$, using a nitrogen cell concentration equal to $4 \mathrm{p} \mu \mathrm{ol}$ N/cell (Hoch, 1995 ; Meksumpun et al., 1995). Dinoflagellates (mainly represented by Dinophysis sp. during summer flagellate blooms in this coastal area) do not represent all flagellates exactly; so this comparison remains qualitative, and only points out a relative similarity in both trends, except for 1989 and 1993. The role of stratification in flagellate production is also illustrated by comparing surface and bottom calculated concentrations of flagellates and diatoms in the river plume (box No 3) during 1995 ; Figure 6 shows the prevalence of flagellates in surface water, when diatoms are more uniformly distributed, except for the blooming period.

\subsection{Zooplankton biomass}

The seasonal fluctuation of zooplankton biomass in the Seine river plume (box No 3) is shown in Figure 7, and the comparison with chlorophyll $a$ evolution indicates increasing zooplankton biomass after the main blooming period. Few quantitative data are available for the annual zooplankton cycle in this area, but recent observations of biomasses in the plume (Le Fèvre-Lehoërff, pers. com.), which reach $300 \mu \mathrm{g} / \mathrm{dm}^{3}$ dry weight during the summer, are consistent with calculated values.

\subsection{Particulate phosphorus}

Particulate exchangeable phosphate in suspended matter and sediment

The simulated concentrations of particulate exchangeable phosphate in suspended matter (boxes 1 and 3) were compared with all available data, measured in the estuary mouth in 1992 by Aminot et al. (1993). These observed values, ranging from $20 \mu \mathrm{mol} / \mathrm{g}$ to $34 \mu \mathrm{mol} / \mathrm{g}$, coincide well with calculated values in box 1, and are slightly higher than calculated concentrations in box 3 (Fig. 8). A standard deviation between simulated and observed values was calculated as for nutrients, with a value of 0.074 , indicating a good fit.

In sediments located under the plume, the exchangeable phosphate concentrations measured in 1992 and 1994 by Andrieux and Aminot (1997) range from $1.1 \mu \mathrm{mol} / \mathrm{g}$ to $2.7 \mu \mathrm{mol} / \mathrm{g}$ (Fig. 8), and are much lower than exchangeable phosphate concentrations in suspended matter. These concentrations in sediment coincide with simulated values in corresponding locations (sediments under water boxes Nos. 3 and 4), excepting an underestimation by the model during the year 1994 ; the standard deviation between simulated and observed values is equal to 0.092. The exchangeable phosphate concentrations measured in sediments all over the Bay in February 1992 (Fig. 9) exhibit a horizontal gradient with values increasing from the open sea to the estuary. This spatial configuration is quite well reproduced by calculated concentrations, although the model overestimates western concentrations, because the probable variations of maximal phosphate adsorption capacity in sediments, due to the gradient of fine-grained sediments in the Bay, are not taken into account.

\section{Detrital organic phosphorus in suspended matter and sediment}

The calculated organic phosphorus concentrations in suspended matter, mainly resulting from phytoplankton and zooplankton mortality, vary much more than exchangeable phosphate concentrations ; for instance, calculated concentrations in the plume area (box 3) range from $3 \mu \mathrm{mol} / \mathrm{g}$ in winter to $240 \mu \mathrm{mol} / \mathrm{g}$ in summer (Fig. 10). These values are in fairly good agreement with available measurements taken in the estuary mouth by Andrieux-Loyer (1997) and the standard deviation is 
equal to 0.23 . She observed a minimum organic phosphorus concentration in suspended matter equal to $17 \mu \mathrm{mol} / \mathrm{g}$ in winter 1992, and a maximum reaching $200 \mu \mathrm{mol} / \mathrm{g}$ in spring. According to the author, the latter value is related to phytoplanktonic blooms producing temporary increases in detrital organic phosphorus in suspended matter, during the spring/summer period.

Although seasonal variations of organic phosphorus can be simulated in sediment, and appear to be consistent with the magnitude order of measurements and with the increase in organic phosphorus concentrations after the bloom period (Andrieux and Aminot, 1997), the calculated concentrations in sediments under the box 3 do not fit well with measurements performed around this location (Fig. 10). Moreover, the spatial heterogeneity of organic phosphorus concentrations in the sediment all over the Bay is not well simulated.

\subsection{Nutrient limiting effects}

Following its validation, this model has been used to estimate the limiting effect of nutrient concentrations on diatom and flagellate growth in the plume area (box No 12) and in an offshore station (box No 31), during the year 1995. The limiting factors were calculated for each nutrient, and are equal to $1-(\mathrm{X} /(\mathrm{X}+\mathrm{Kx}))$, with $\mathrm{X}=$ nutrient concentration in water, and $\mathrm{Kx}=$ nutrient half saturation constant for diatoms or flagellates (see table 1). These calculated factors range from 0 (no limitation) to 1 (total limitation). In the plume, diatoms are limited by phosphate in spring and by silicate in summer ; flagellates are limited by nitrogen and phosphate after the $200^{\text {th }}$ day, which corresponds to the beginning of their productive period (Fig. 11). In the offshore station, diatoms are mainly limited by silicate in spring, and by nitrogen in summer ; flagellates are highly limited by nitrogen. These results are consistent with measurements by Bauerfeind et al. (1990) who observed a potential phosphate and silicate limitation for diatom blooms in the coastal waters of the south-eastern North Sea, while nitrogen is the main limiting element in the more offshore areas. In the estuary (box No 1), a similar approach shows that light is the first limiting factor, because of the high estuarine turbidity ; this light limitation decreases from the estuary towards the less turbid waters in the Bay.

\section{Discussion}

The present model, including phosphorus, allows the third major nutrient controlling phytoplanktonic production in the Bay of Seine to be taken into account. Calculation of standard deviations between observed and simulated data shows that the model correctly reproduces dissolved nutrient behaviour in the coastal zone enriched by river inputs, and seasonal cycles of diatoms with high biomass values in the eutrophicated plume area during the bloom period. Furthermore, the drop in standard deviation values, compared with those of the previous model, reveals an improvement of the modelling approach related to the introduction of phosphorus.

With regard to flagellate production, the model highlights the importance of stratification in the plume area. However, the two-layer structure is not precise enough to reproduce high concentrations of flagellates observed on the pycnocline level in stratified areas (Gentien et al., 1995 ; Maggi et al., 1992 ; Peperzak et al., 1996). More realistic simulations of these processes would require an integral 3D model, which is currently being developed (Cugier, 1999 ; Cugier and Le Hir, submitted).

The simulated concentrations of zooplankton are consistent with observed values in the plume area, and are higher than usual observations along the English Channel coast ranging from 50 to $200 \mu \mathrm{g} / \mathrm{dm}^{3}$ dry weight (Le Fèvre-Lehoërff et al., 1993). They reveal the high level of zooplanktonic production linked to intense primary production in this plume ecosystem.

Particulate variables in suspended matter, like exchangeable phosphate and organic phosphorus, are simulated with accuracy and calculated values are within the range of observed concentrations. In contrast, simulated concentrations of exchangeable phosphate in sediment correspond less to values observed all over the Bay ; so in future, spatial variations of maximal phosphorus adsorption capacity related to sedimentary gradients will need to be taken into account. Contrary to exchangeable phosphate in sediment, which is quickly regulated by adsorption/desorption with dissolved phosphate in interstitial water and by diffusion of dissolved phosphate between water and sediment, the concentration of detrital organic phosphorus in sediment is directly related to the simulated thickness of sediment boxes. The latter feature is not well simulated because the model does not take sediment consolidation into account. This process should be included in a future version of the model. Nevertheless, these shortcomings do not rule out phytoplankton modelling, because the stock of 
bioavailable phosphorus in the Bay's sediment is much lower than the phosphate stock in the water column (Andrieux-Loyer, 1997).

For this reason, and given the valuable correspondences between prognosis and real phytoplanktonic biomasses, the present model was used to estimate the consequences of nutrient loading reductions on phytoplanktonic production. Four scenarios were run, consisting in a decrease of $25 \%$ and $50 \%$ in dissolved inorganic nitrogen or dissolved phosphate loading by the Seine river in 1995. Results are presented in terms of reduction of gross diatom and flagellate production in the Bay, and reduction of maximum concentrations reached by both phytoplanktonic groups in the plume (Table 2). Results show that $\mathrm{N}$ and $\mathrm{P}$ loading reductions induce a slight decrease of gross diatom production because about $90 \%$ of the annual diatom production in the Bay takes place outside of the plume. This offshore production is mainly regulated by silicate and nitrogen inputs through seaward boundaries, and by regeneration of nutrients (Maguer et al., 1998). On the contrary, gross flagellate production is significantly lowered, particularly by the nitrogen loading reduction; this is due to the fact that the flagellate production area is mainly restricted to the river plume, which is more directly influenced by Seine river inputs. The reduction of nitrogen loading has no effect on maximum diatom concentrations in the plume, whereas the reduction of phosphate input induces a decrease of these concentrations, due to the emergence of a phosphate limiting effect for diatoms during the first spring bloom in this plume area. During the summer, silicate is often the first limiting nutrient for diatom blooms in the river plume, and nitrogen loading reductions have no effect on maximum diatom concentrations. Maximum flagellate concentrations are greatly lowered by nitrogen or phosphate loading reductions because of the link between flagellate production and the enrichment of the stratified plume area by river inputs. The last scenario run consisted in removing particulate forms of phosphorus loading (exchangeable phosphate and organic phosphorus) from the Seine river. This simulation shows a decrease in the spring diatom bloom in the plume (-22\%) and a reduction of flagellate production in the same area ($26 \%$ ). This pattern confirms the relative importance of particulate phosphorus load in the Bay of Seine, previously pointed out by Aminot et al. (1993).

\section{Conclusion}

This study shows that introducing phosphorus in the model improves the accuracy of biogeochemical modelling, and shows up the emergence of a vernal limiting effect of phosphorus in the Seine plume area. For instance, Figure 12, showing the comparison between limiting effect of nutrients for diatoms in 1978 and 1995, highlights the control of diatom growth by phosphorus in spring 1995, while this nutrient was not limiting in 1978. This result is in good agreement with several observations in plume ecosystems, where diatom production may switch from phosphate limitation in the spring, to nitrogen or silicate limitation in summer. For instance, Howarth (1988) and Peeters and Peperzak (1990) found similar patterns in the Patuxent estuary and in the Dutch coastal waters, respectively. Previous works have highlighted the enhancement of flagellate production by high $\mathrm{N} / \mathrm{Si}$ ratios in stratified river plumes (Guillaud and Ménesguen, 1998 ; Peperzak et al., 1996 ; Radach, 1992). The present study completes these results and specifies the potential limitation of summer flagellate production in the Seine river plume, not only by nitrogen, but also by phosphate. The emergence of a phosphate limiting effect for phytoplankton in the river plume must be related to the decrease in the phosphate load during the period 1976-1995. The rate of this evolution is about $-2.7 \%$ per year, and is mainly due to the reduction of industrial effluents from fertiliser factories in the watershed (Menesguen et al., 1995) ; the lack of an obvious phosphate limiting effect in the simulations of the former years (1976-1980) can be attributed to higher phosphorus loads in the late 1970s (about $15000 \mathrm{t} / \mathrm{y}$ in the past compared to $11000 \mathrm{t} / \mathrm{y}$ today). Contrary to phosphate, the nitrogen load increased during the period 1976-1995 (+1.8\% per year), due to agriculture and urban development, which is why the present calculated nitrogen limitation is less severe than the nitrogen limiting effect in the past. These features are consistent with model simulations for impacts of hypothetical nutrient loading reductions, which point out a potential decrease in flagellate production in the plume, related to nitrogen or phosphate loading reduction. With regard to diatoms, the reduction of phosphate loading induces a lowering of the diatom concentrations in the plume during the spring bloom.

The present study shows the great potential of this sort of model to better choose a nutrient reduction policy for the watershed, and to control effect of eutrophication in the Bay of Seine. Nevertheless, simulations of phytoplanktonic production in the Bay of Seine, and study of exploratory nutrient 
reduction scenarios, should be improved by further developments of the model concerning the introduction of a real, three-dimensional structure, variable phosphate adsorption capacities related to the sedimentary gradient in the Bay, and sediment consolidation modelling.

\section{Acknowledgements}

This work was supported by the PNOC (Programme National d'Océanographie Côtière) Research Programme on the "Baie de Seine". We would like to thank R. Kerouel and P. Cann for their helpful collaboration for marine data acquisition and sample analysis, and we are grateful to A. Aminot for his contribution to the interpreting of results.

\section{References}

Agoumi, A., 1985. Modélisation de l'écosystème pélagique en Manche. Etude de l'influence des phénomènes physiques sur le système planctonique. Thesis, Université Pierre et Marie Curie, Paris. 303 p.

Aksnes, D. L., Ulvestad, K. B., Balino, B. M., Bernsten, J., Egge, J. K. and Svendsen E., 1995. Ecological modelling in coastal waters: towards predictive physical-chemical-biological simulation models. Ophelia, 41 : 5-36.

Aminot, A., Guillaud J.F. and Andrieux F., 1993. Spéciation du phosphore et apports en Baie de Seine orientale. Oceanol. Acta., 16(5-6) : 617-623.

Aminot, A. and Andrieux, F., 1996. Concept and determination of exchangeable phosphate in aquatic sediments. Water Res., 30(11) : 2805-2811.

Aminot, A., Guillaud, J. F. and Kérouel, R., 1997. La baie de Seine: hydrologie, nutriments et chlorophylle (1978-1994). Edition IFREMER, Repères Océan, 14 : 148 p.

Andersen, V., 1985. Modélisation d'écosystèmes pélagiques. Etudes de processus. Thesis , Université Pierre et Marie Curie, Paris. 135 p.

Andersen, V. and Nival, P., 1989. Modelling of phytoplankton dynamics in an enclosed water column. J. Mar. Biol. Ass. U.K, 69 : 625-646.

Andrieux-Loyer, F., 1997. Les formes de phosphore particulaire et sedimentaire en environnement côtier. Methodes d'analyse, biodisponibilité, échange. Thesis, Université de Bretagne Occidentale, Brest. 312 p.

Andrieux, F. and Aminot, A, 1997. A two year survey of phosphorus in the sediments of the Bay of Seine (France). Cont. Shelf Res., 17 (10) : 1229-1245.

Azam, F., Fenchel, T., Field, J. G., Gray, J. S., Meyer Rail, L. A. and Thingstad, F., 1983. The ecological role of water column microbes in the sea. Mar. Ecol. Progr. Ser., 10 : 257-263.

Bauerfeind, E., Hickel, W., Niermann, U. and Westernhagen, H. V., 1990. Phytoplankton biomass and potential limitation of phytoplankton development in the southeastern North Sea in spring 1985 and 1986. Netherl. J. Sea Res., 25 (1/2) : 131-142.

Belin, C. and Raffin, B., 1998. Les espèces phytoplanctoniques toxiques et nuisibles sur le littoral français de 1984 à 1995, résultats du REPHY. Edition IFREMER, Rapp. Sc. Tech. DEL/MPAO 98-16. 125 p.

Bentley, D. and Maillard-Quisthoudt, C., 1990. Caractéristiques physicochimiques de profils côte-large en Manche centrale. J. Rech. Océanog., 15 : 135-141.

Chapelle, A., 1995. A preliminary model of nutrient cycling in sediments of a Mediterranean lagoon. Ecol. Model., 80 : 131-147.

Cellule Antipollution de la Seine (1976 à 1995). Etude des pollutions en Seine, Ministère de l'Environnement, Service Maritime de la Seine Maritime (Troisième Section).

C.N.E.X.O. - Centre National pour l’Expoitation des Océans., 1980. Campagnes Ecomanche III. Etat de référence écologique de la Manche. Résultats des campagnes à la mer, No 21-1. CNEXO (Editors). $60 \mathrm{p}$.

Cugier, P. and Le Hir, P.,1998. Development of a 3D hydrodynamical model for coastal ecosystem modelling. Application to the plume of the Seine River. Estuar. Coast. Shelf Sc. (submitted).

Cugier, P., 1999. Modélisation du devenir à moyen terme dans l'eau et le sédiment des éléments majeurs (N, P, Si, O) rejetés par la Seine en baie de Seine. Thèse de doctorat, Univ. de Caen, $241 \mathrm{p}$. 
De Jonge, V. N., Boynton, W., D’Elia, C. F., Elmgren, R. and Welsh, B. L., 1994. Responses to developments in eutrophication in four different North Atlantic estuarine systems. In : K. R. Dyer and R. J Orth (Editors), Changes in Fluxes in estuaries: implications from Science to Management. Olsen \& Olsen, Fredensborg. pp. 179-196.

Eppley, R. W., Rogers, J. N. and McCarthy, J. J., 1969. Half-saturation constants for uptake of nitrate and ammmonium by marine phytoplankton. Limnol. Oceanogr., 14 : 912-920. 1085.

Eppley, R. W., 1972. Temperature and phytoplankton growth in the sea. Fish. Bull., 70 : 1063-

Furumai, H., Kondo, T. and Ohgaki, S. 1989. Phosphorus exchange kinetics and exchangeable phosphorus form in sediments. Water Res., $6: 685-691$.

Gentien, P., Lunven, M., Lehaître, M. and Duvent, J. L., 1995. In-situ depth profiling of particle sizes. Deep-Sea Res., 42 (8) : 1297-1312.

Guillaud, J.-F. and Ménesguen, A., 1998. Modélisation sur vingt ans (1976-1995) de la production phytoplanctonique en baie de Seine (France). Oceanol. Acta, 21 (6) : 887-906.

Hoch, T., 1995. Modélisation du cycle biogéochimique des éléments limitant la production biologique en Manche (N, P, Si). Thesis, Université Paris VII. 205 p.

Hoch, T., 1998. Modélisation du réseau trophique pélagique et de la production primaire en Manche. Oceanol. Acta, 21 (6) : 871-885.

Howarth, R. W., 1988. Nutrient limitation of net primary production in marine ecosystems. Ann. Rev. Ecol., 19 : 89-110.

I.O.S. - Institute of Oceanographic Sciences, 1987. Geochimical studies in the English Channel. Cruise report No 192. Natural Environment Research Council (Editors). 40 p.

Ives, J. D., 1987. Possible mechanisms underlying copepods grazing response to level of toxicity in red tide dinoflagellates. J. Exp. Mar. Biol. Ecol., 112 (2) : 131-145.

Jorgensen, S. E., 1979. Handbook of environmental data and ecological parameters. International Society for Ecological Modelling- [ISEM] (Editors), Vaerlose (DK), 1162 p.

Justic, D., 1991. Long-term eutrophication of the northern Adriatic Sea. Mar. Pollut. Bull., $18: 281-284$.

Le Fèvre-Lehoërff, G., Erard-Le Denn, E. and Arzul, G., 1993. Planktonic ecosystems in the Channel. Trophic relations. Oceanol. Acta,. 16 : 661-670.

Le Grand, J., 1994. Bilan du réseau de surveillance phytoplanctonique en Normandie (19891992). IFREMER, Rapport interne DEL / 94.09 / Port-en Bessin. 72 p.

Le Pape, O., 1996. Modélisation des cycles biogéochimiques des éléments limitant la production phytoplanctonique en Rade de Brest. Thesis, Ecole Nationale Supérieure Agronomique de Rennes. 195 p.

Le Pape, O. and Ménesguen, A., 1997. Hydrodynamic prevention of eutrophication in the Bay of Brest (France), a modelling approach. J. Mar. Syst., 12 : 171-186.

Lorenzen, C. J. 1966. A method for the continuous measurement of in vivo chlorophyll concentration. Deep Sea Res., 13 : 223-227.

Maggi, P., Truquet, P., Mornet, F. et Lassus, P., 1992. Distribution verticale, à basse et pleine mers, du phytoplancton estival en baie de Seine. IFREMER, Rapport interne DEL / 92.06 / Nantes. $22 \mathrm{p}$.

Maguer, J.-F., L'Helguen, S., Madec, C. and Le Corre, P. 1998. Absorption et régénération de l'azote dans le système brassé de la Manche : productions nouvelle et régénérée. Oceanol. Acta, 21 (6) : 861-870.

Meksumpun, S., Montani, S., Ichimi, K., Tada, K., Yoshimatsu, S. and Okaichi, T., 1995. Relationships between the biochimical composition and the environmental conditions of Gymnodinium sp. red tide in the Seto inland sea. In : P. Lassus, G. Arzul, E. Erard, P. Gentien and C. Marcaillou (Editors), Harmful Marine Algal Blooms. Technique et Documentation - Lavoisier, Intercept Ltd, 1995.pp. 621-626.

Ménesguen, A., 1991. "ELISE", an interactive software for modelling complex aquatic ecosystems. In : Arcilla et al. (Editors), Computer Modelling in Ocean Engineering 91. Balkema, Rotterdam. pp. 87-94.

Ménesguen, A., Guillaud, J-F., Aminot, A. and Hoch, T., 1995. Modelling the eutrophication in a river plume: the Seine river case study (France). Ophelia. $42: 205-225$. 
Ménesguen, A. and Hoch, T., 1997. Modelling the biogeochemical cycles of elements limiting primary production in the English Channel. I. Role of thermohaline stratification. Mar. Ecol. Prog. Ser., 146 : 173-188.

Paasche, E., 1973. Silicon and the ecology of marine plankton diatoms.II Silicate-uptake kinetics in five diatom species. Mar. Biol., 19 : 262-269.

Peeters, J. C. H. and Peperzak, L., 1990. Nutrient limitation in the North Sea: a bioassay approach. Neth. J. Sea Res., 26 (1) : 61-73.

Peperzak, L., Snoeijer, G. J., Dijkema, R., Gieskes, W. W. C., Joordens, J., Peeters, J. C. H., Schol, C., Vrieling, E. G. and Zevenboom, W., 1996. Development of a Dinophysis acuminata bloom in the river Rhine plume (North Sea). In : T. Yasumoto, Y. Oshima and Y. Fukuyo (Editors), Harmful and Toxic Algal Blooms. Intergovernmental Oceanographic Commission of UNESCO, 1996. pp. 273276.

Peterson, D. H. and Festa, J. F., 1984. Numerical simulation of phytoplankton productivity in partially mixed estuaries. Estuar. Coast. Shelf Sc., 19 : 563-589.

Psenner, R., Boström, B., Dinka, M., Petterson, K., Pucsko, R. and Sager, M., 1988. Fractionation of phosphorus in suspended matter and sediment. Arch. Hydrobiol., Beih. Ergebn. Limnol., 30 : 98-103.

Radach, G., 1992. Ecosystem functioning in the German Bight under continental nutrient inputs by rivers. Estuaries, $15:$ 477-496.

Rao, C.R.M. and Reddi, G.S., 1990. Decomposition procedure with aqua regia and hydrofluoric acid at room temperature for the spectrophotometric determination of phosphorus in rocks and minerals. Anal. Chim. Acta, 237 : 251-252.

Redfield, A.C., Ketchum, B.H., et Richards, F.A., 1963. The influence of organisms on the composition of sea water. In: : M.N. Hill (Editor), The Sea, V.2. Interscience. pp. 26-77.

R.N.O. - Réseau National d’Observation de la Qualité du Milieu Marin, 1976-1984. Recueil des observations. Campagnes 1976 à 1984. Ministère de l’Environnement - CNEXO (editor).

Salomon, J.-C. and Breton, M., 1991. Courants résiduels de marée dans la Manche. Oceanol. Acta, $11: 47-53$.

Soulsby, R. L., Hamm, L., Klopman, G., Myrhaug, D., Simons, R. R. and Thomas, G. P. 1993. Wave-current interaction within and outside the bottom boundary layer. Coast. Eng.., 21 : 41-69.

Steele, J. H., 1962. Environmental control of photosynthesis in the sea. Limnol. Oceanogr., 7 (2) : 137-150.

Steele, J. H. and Henderson, E. W., 1992. The role of predation in plankton models. J. Plankt. Res., 14 (1) : 157-172.

Strickland, J.D.H. and Parsons, T.R. 1972. A practical handbook of sea water analysis. Bull. Fish. Res. Bd. Can. : 167, 311 p.

Tappin, A. D., 1988. Studies of trace metals in shelf waters of the British Isles. Thesis, University of Southampton. $332 \mathrm{p}$.

Titman, D. and Kilham, P., 1976. Sinking in freshwater phytoplancton: some ecological implications of cell nutrient status and physical mixing processes. Limnol. Oceanogr., 21 : 409-417.

Varela, R. A., Cruzado, A. and Gabaldon, J. E., 1995. Modelling primary production in the North Sea using the European Regional Seas Ecosystem Model. Neth. J. Sea Res. 33 (3/4) : 337-361.

Videau, C., Ryckaert, M. and L'Helguen, S., 1998. Phytoplancton en Baie de Seine. Influence du panache fluvial sur la production primaire. Oceanol. Acta, 21 (6) : 907-922.

Williams, J.D.H., Jaquet, J.-M. and Thomas, R.L., 1976. Forms of phosphorus in the surficial sediments of lake Erie. J. Fish. Res. Bd. Can., 33 : 413-429. 
Table 1 : Parameters of the biological model

\begin{tabular}{|c|c|c|c|c|}
\hline Symbol & Meaning & Unit & Value & References \\
\hline \multicolumn{5}{|l|}{ Diatoms } \\
\hline$\mu_{\text {maxdiat }}$ & Maximum growth rate at $0^{\circ} \mathrm{C}$ & $\mathrm{d}^{-1}$ & 0.55 & Le Pape and Ménesguen, 1997 \\
\hline $\mathrm{I}_{\text {satdiat }}$ & Optimal light intensity & $\mathrm{W} \mathrm{m} \mathrm{m}^{-2}$ & 55 & calibration \\
\hline $\mathrm{K}_{\text {Ndiat }}$ & Half saturation constant for $\mathrm{N}$ & $\mu \mathrm{mol} \mathrm{dm}{ }^{-3}$ & 2 & Eppley et al., 1969 \\
\hline $\mathrm{K}_{\text {Sidiat }}$ & Half saturation constant for $\mathrm{Si}$ & $\mu \mathrm{mol} \mathrm{dm}{ }^{-3}$ & 1 & Paasche, 1973 \\
\hline $\mathrm{K}_{\text {Pdiat }}$ & Half saturation constant for $\mathrm{P}$ & $\mu \mathrm{mol} \mathrm{dm}{ }^{-3}$ & 0.15 & Aksnes et al., 1995 \\
\hline $\mathrm{V}_{\text {sdiatmin }}$ & Minimal sedimentation velocity & $\mathrm{m} \mathrm{d}^{-1}$ & 0.5 & Videau et al., 1998 \\
\hline $\mathrm{V}_{\text {sdiatmax }}$ & Maximal sedimentation velocity & $\mathrm{m} \mathrm{d}^{-1}$ & 1.2 & Videau et al., 1998 \\
\hline $\mathrm{m}_{\text {diat }}$ & Mortality rate at $0^{\circ} \mathrm{C}$ & $\mathrm{d}^{-1}$ & 0.035 & Hoch, 1995 \\
\hline $\mathrm{r}_{\mathrm{Si} / \mathrm{N}}$ & Si/N ratio & $\mathrm{mol} \mathrm{mol}^{-1}$ & 0.4 & Aminot et al., 1997 \\
\hline $\mathrm{r}_{\mathrm{P} / \mathrm{N}}$ & $\mathrm{P} / \mathrm{N}$ ratio & $\mathrm{mol} \mathrm{mol}^{-1}$ & 0.0625 & Redfield et al.,1963 \\
\hline $\mathrm{R}_{\mathrm{N} / \text { chloro }}$ & $\mathrm{N} /$ chlorophyll $a$ ratio & $\mathrm{mol} \mathrm{g}^{-1}$ & 0.75 & Jorgensen, 1979 \\
\hline \multicolumn{5}{|c|}{ Flagellates } \\
\hline$\mu_{\text {maxflag }}$ & Maximum growth rate at $0^{\circ} \mathrm{C}$ & $\mathrm{d}^{-1}$ & 0.25 & Peterson and Festa, 1984 \\
\hline $\mathrm{I}_{\text {satflag }}$ & Optimal light intensity & $\mathrm{W} \mathrm{m}^{-2}$ & 180 & Andersen, 1985 \\
\hline $\mathrm{K}_{\mathrm{Nflag}}$ & Half saturation constant for $\mathrm{N}$ & $\mu \mathrm{mol} \mathrm{dm} \mathrm{dm}^{-3}$ & 3 & Le Pape, 1996 \\
\hline$K_{\text {Pflag }}$ & Half saturation constant for $\mathrm{P}$ & $\mu \mathrm{mol} \mathrm{dm} \mathrm{dm}^{-3}$ & 0.10 & Aksnes et al., 1995 \\
\hline $\mathrm{m}_{\text {flag }}$ & Mortality rate at $0^{\circ} \mathrm{C}$ & $\mathrm{d}^{-1}$ & 0.03 & calibration \\
\hline \multicolumn{5}{|c|}{ Zooplankton } \\
\hline$\mu_{\operatorname{maxzoo}}$ & Maximum growth rate at $0^{\circ} \mathrm{C}$ & $\mathrm{d}^{-1}$ & 0.3 & Le Pape, 1996 \\
\hline Ass & Assimilation & dimensionless & 0.6 & Azam et al., 1983 \\
\hline Iv & Slope of Ivlev function & $\mathrm{dm}^{3} \mu \mathrm{g}^{-1}$ & 0.24 & Hoch, 1995 \\
\hline $\mathrm{Pr}_{\text {th }}$ & Chlorophyll predation threshold & $\mu g \mathrm{dm}^{-3}$ & 1 & Le Pape, 1996 \\
\hline $\operatorname{excr}_{\text {zoo }}$ & Excretion & $\mathrm{d}^{-1}$ & 0.01 & Le Pape, 1996 \\
\hline$m_{\operatorname{minzoo}}$ & Minimum mortality rate at $0^{\circ} \mathrm{C}$ & $\mathrm{d}^{-1}$ & 0.06 & Le Pape, 1996 \\
\hline$m_{\mathrm{fzoo}}$ & Biomass dependent mortality rate at $0^{\circ} \mathrm{C}$ & $\mathrm{d}^{-1} \mu \mathrm{g}^{-1} \mathrm{dm}^{3}$ & 0.0005 & calibration \\
\hline$r_{N / d w}$ & N/dry weight ratio & $\mu \mathrm{mol} \mu \mathrm{g}^{-1}$ & 0.0031 & Le Fèvre et al., 1993 \\
\hline \multicolumn{5}{|c|}{ Particulate adsorbed phosphorus and detrital organic matter } \\
\hline $\mathrm{k}_{\text {desorp }}$ & Phosphorus desorption rate & $\mathrm{d}^{-1}$ & 2.4 & Andrieux-Loyer, 1997 \\
\hline $\mathrm{k}_{\mathrm{adsorp}}$ & Phosphorus adsorption rate & $\mathrm{d}^{-1} \mathrm{dm}^{3} \mu \mathrm{mol}^{-1}$ & 0.12 & Andrieux-Loyer, 1997 \\
\hline $\mathrm{Q}_{0 \operatorname{maxSM}}$ & $\begin{array}{l}\text { Max. P adsorption capacity (suspended } \\
\text { matter) }\end{array}$ & $\mu \mathrm{mol} \mathrm{g}{ }^{-1}$ & 40 & Andrieux-Loyer, 1997 \\
\hline $\mathrm{Q}_{0 \operatorname{maxSED}}$ & Max. P adsorption capacity (sediment) & $\mu \mathrm{mol} \mathrm{g}{ }^{-1}$ & 5 & Andrieux-Loyer, 1997 \\
\hline $\mathrm{k}_{\operatorname{minN}}$ & $\mathrm{N}$ mineralization rate at $0^{\circ} \mathrm{C}$ & $d^{-1}$ & 0.05 & calibration \\
\hline$k_{\text {nitrif }}$ & Nitrification rate at $0^{\circ} \mathrm{C}$ & $d^{-1}$ & 0.2 & Chapelle, 1995 \\
\hline $\mathrm{k}_{\min \mathrm{P}}$ & $\mathrm{P}$ mineralization rate at $0^{\circ} \mathrm{C}$ & $d^{-1}$ & 0.1 & Hoch, 1995 \\
\hline $\mathrm{k}_{\text {diss }}$ & Si dissolution rate at $0^{\circ} \mathrm{C}$ & $\mathrm{d}^{-1}$ & 0.07 & calibration \\
\hline $\mathrm{v}_{\mathrm{SPOM}}$ & Sedimentation velocity (part. org. matter) & $\mathrm{m} \mathrm{d}^{-1}$ & 0.2 & calibration \\
\hline $\mathrm{v}_{\mathrm{sSM}}$ & Sedimentation velocity (mineral susp. matter) & $\mathrm{m} \mathrm{d}^{-1}$ & 0.3 & calibration \\
\hline$\tau_{\mathrm{cd}}$ & Critical shear stress for deposition & $\mathrm{N} \mathrm{m}^{-2}$ & 0.2 & calibration \\
\hline$\tau_{\mathrm{ce}}$ & Critical shear stress for erosion & $\mathrm{N} \mathrm{m}^{-2}$ & 0.3 & calibration \\
\hline
\end{tabular}


Table 2 : Response of diatom and flagellate production to nitrogen and phosphate loading reduction

\begin{tabular}{|l|c|c|c|c|}
\hline $\begin{array}{c}\text { Nutrient loading } \\
\text { reduction } \\
(\%)\end{array}$ & $\begin{array}{c}\text { Reduction of } \\
\text { diatom production } \\
\text { in the Bay } \\
(\%)\end{array}$ & $\begin{array}{c}\text { Reduction of } \\
\text { flagellate production } \\
\text { in the Bay } \\
(\%)\end{array}$ & $\begin{array}{c}\text { Reduction of max. } \\
\text { diatom concentration } \\
\text { in the plume } \\
(\%)\end{array}$ & $\begin{array}{c}\text { Reduction of max. } \\
\text { flagellate concentration } \\
\text { in the plume } \\
(\%)\end{array}$ \\
\hline $\begin{array}{l}25 \% \mathbf{N} \\
\text { reduction }\end{array}$ & $2 \%$ & $33 \%$ & $0 \%$ & $50 \%$ \\
\hline $\begin{array}{l}50 \% \mathbf{N} \\
\text { reduction }\end{array}$ & $8 \%$ & $51 \%$ & $0.5 \%$ & $97 \%$ \\
\hline $\begin{array}{l}25 \% \mathbf{P} \\
\text { reduction }\end{array}$ & $0.5 \%$ & $24 \%$ & $16 \%$ & $69 \%$ \\
\hline $\begin{array}{l}50 \% \mathbf{P} \\
\text { reduction }\end{array}$ & $1 \%$ & $35 \%$ & $34 \%$ & $91 \%$ \\
\hline
\end{tabular}

Fig 1 : Bay of Seine situation and box model splitting

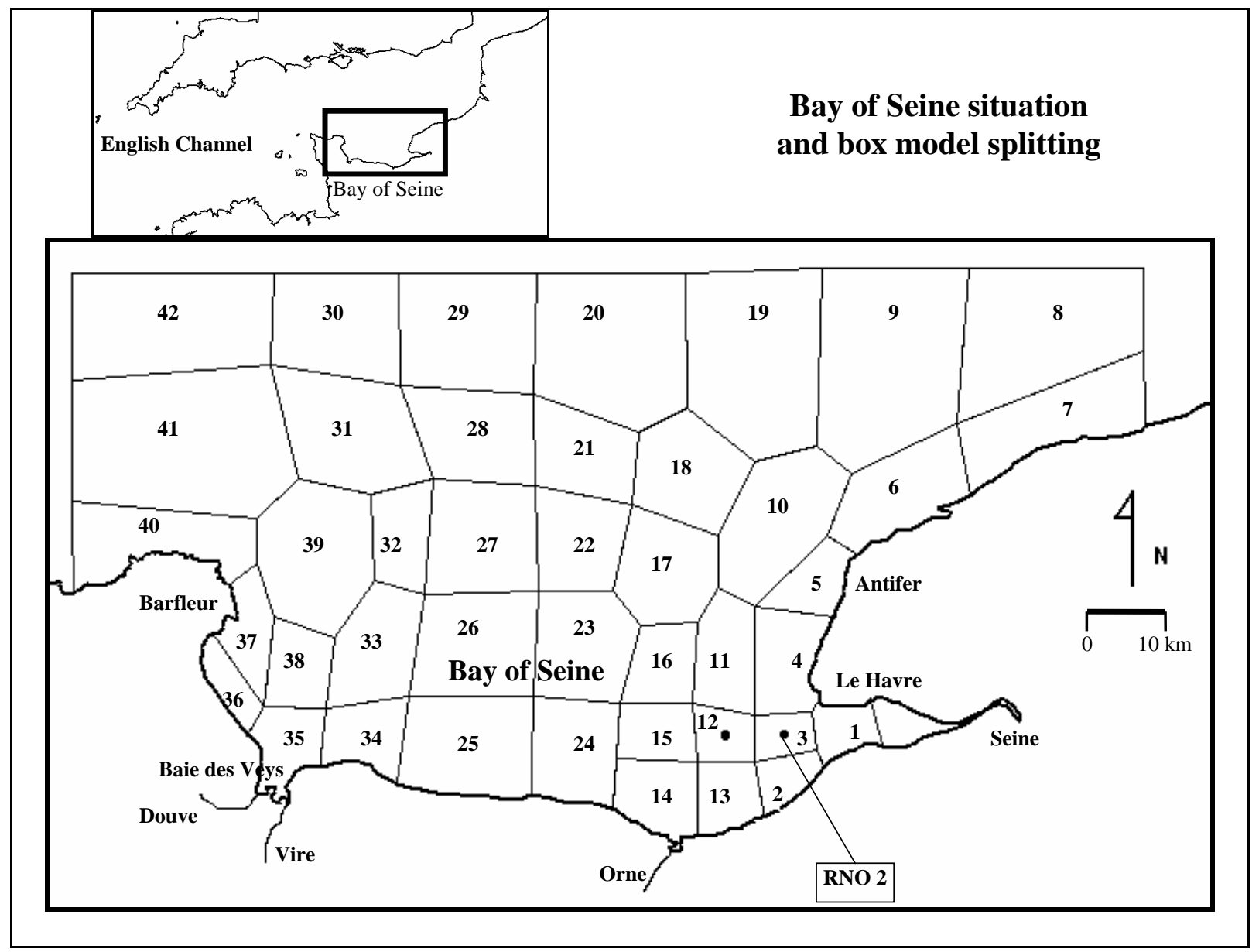


Fig 2 : Conceptual diagram of phosphorus cycling

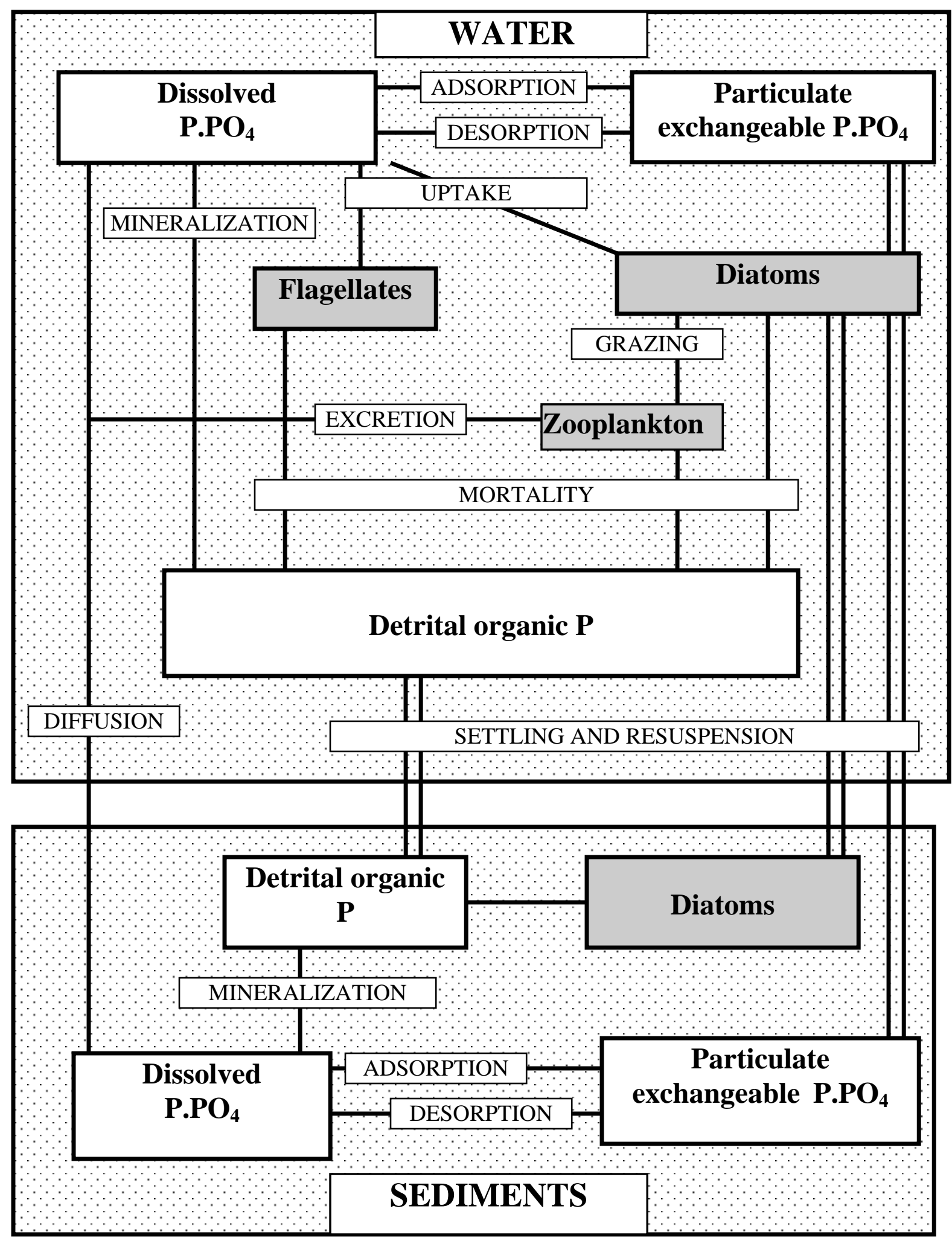


Fig 3 : Time series of measured and simulated surface dissolved inorganic nitrogen, silicate, phosphate and chlorophyll a concentrations in the plume (RNO 2 / box No 3) for the period 1976-1984
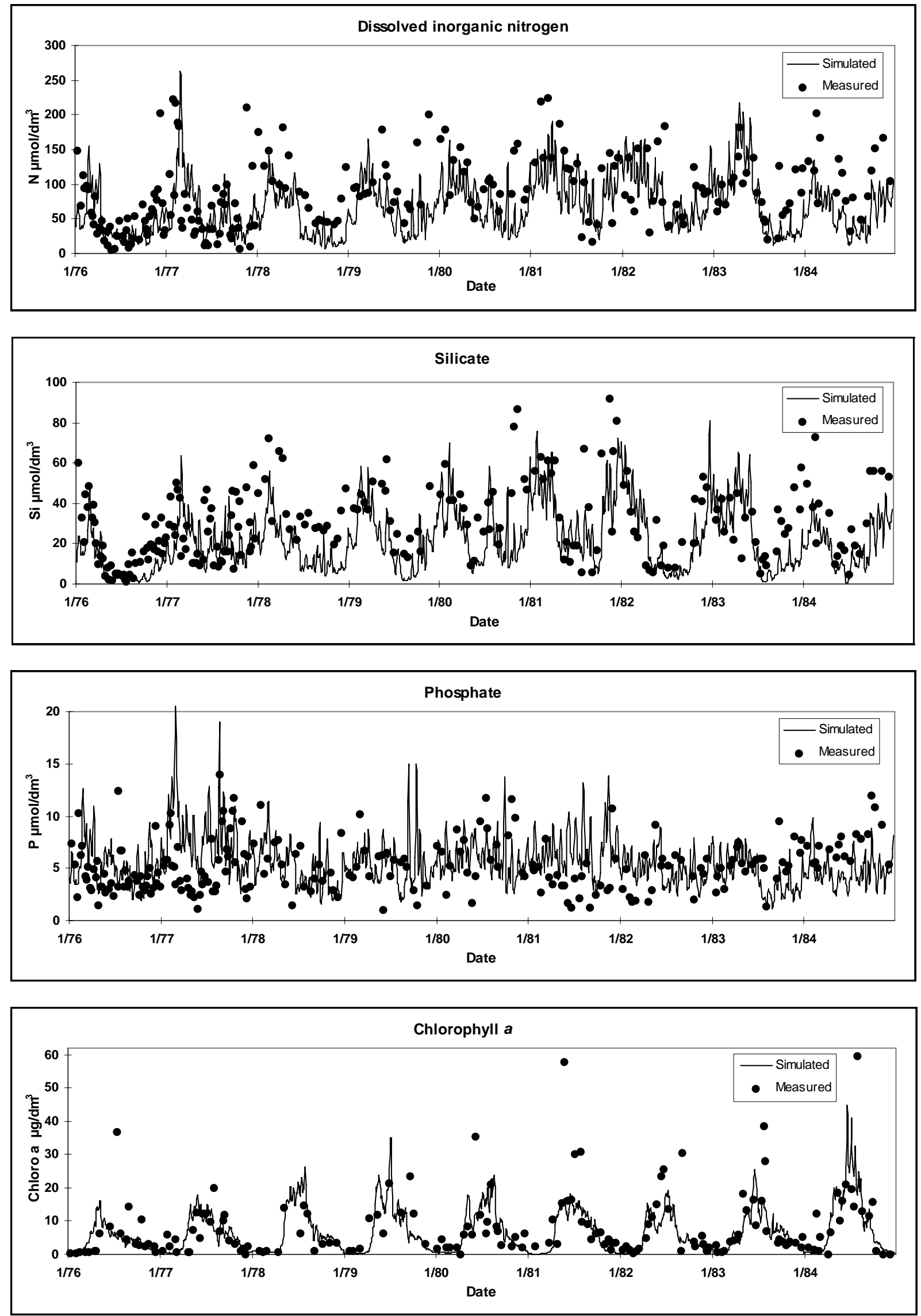
Fig 4 : Comparison between measured and calculated chlorophyll $a$ concentrations in the Bay of Seine (June 1992)

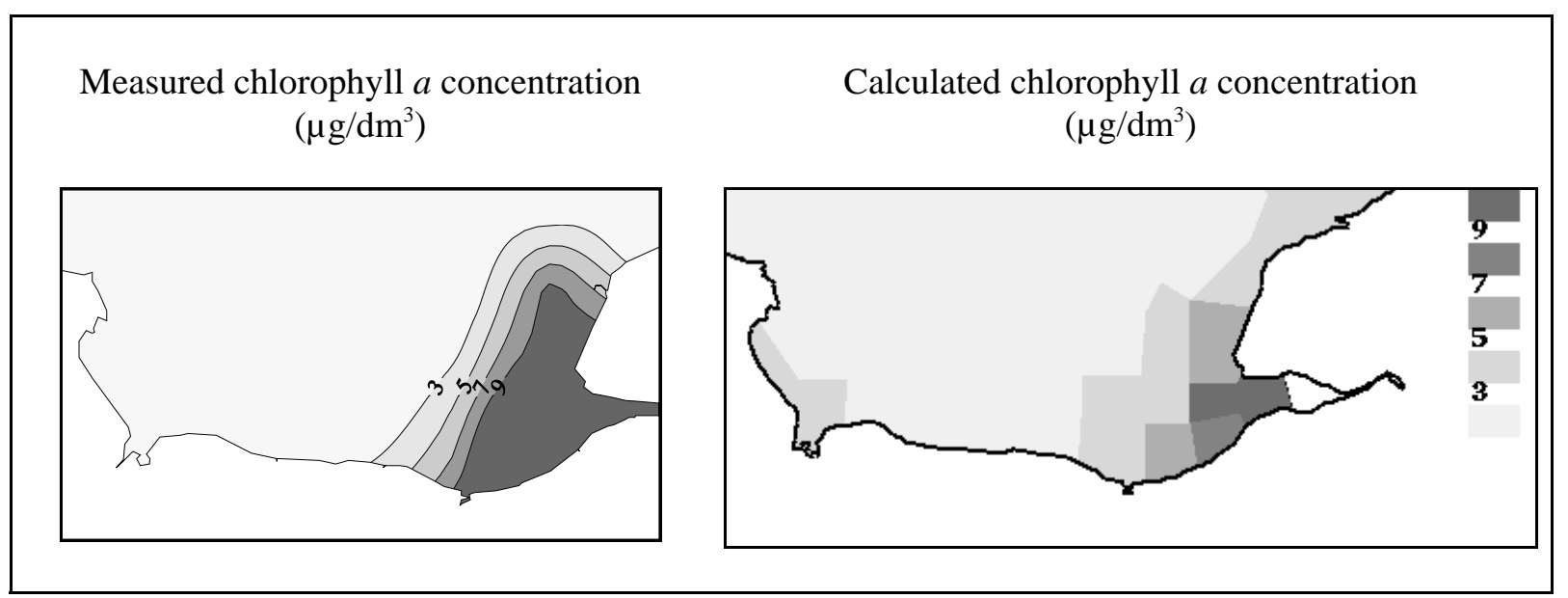

Fig 5: Comparison between yearly maximum concentrations of measured dinoflagellates and simulated flagellates for the period 1983-1995

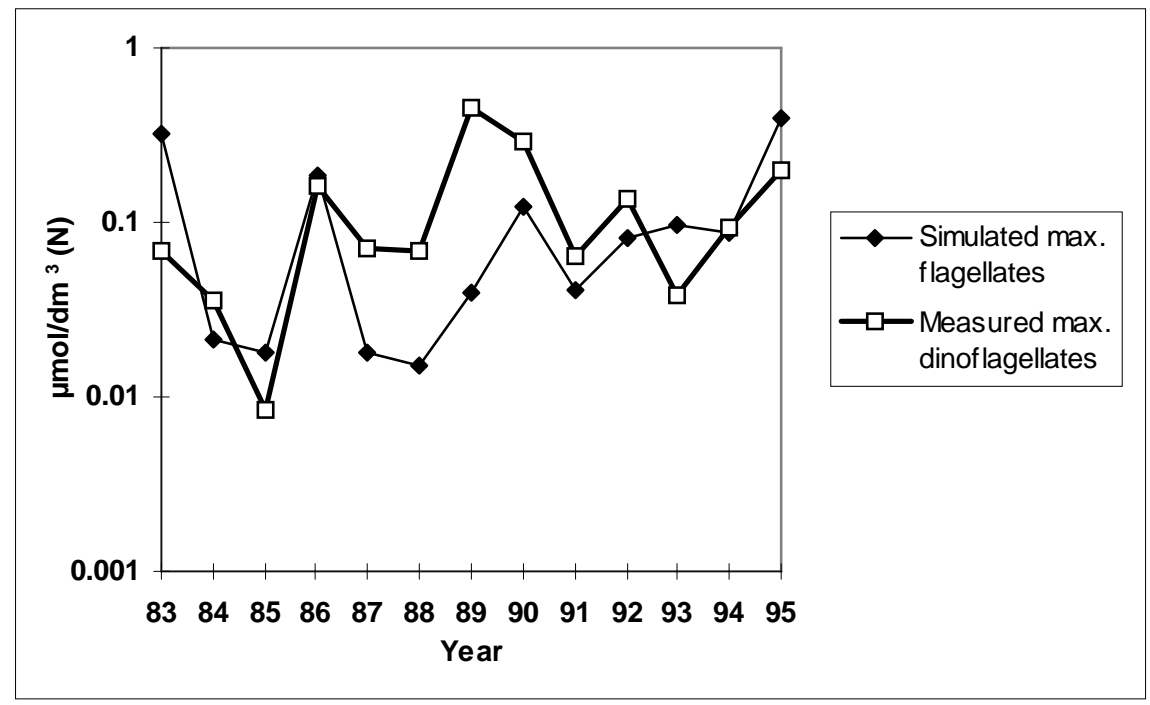


Fig 6 : Surface and bottom calculated concentrations of flagellates and diatoms in the river plume (box No 3) during the year 1995

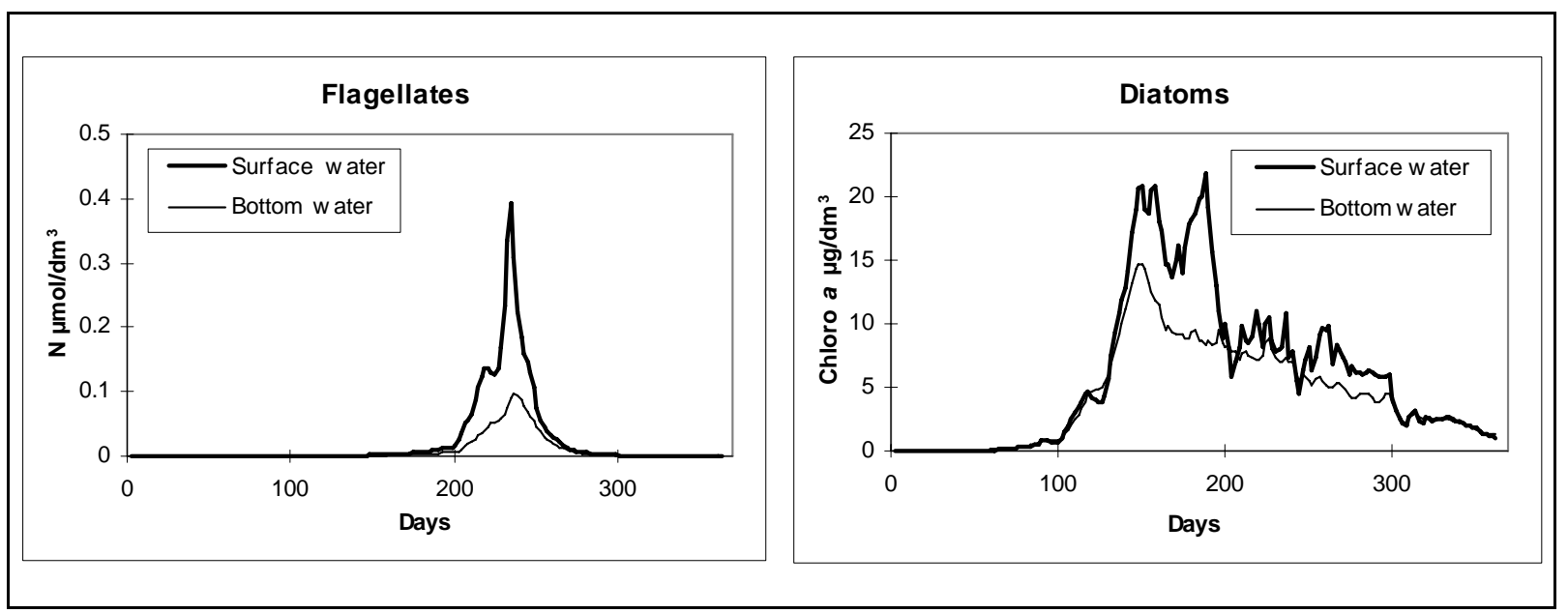

Fig 7 : Time series of simulated surface zooplanktonic biomass and chlorophyll a concentrations in the box No 3 for the year 1995

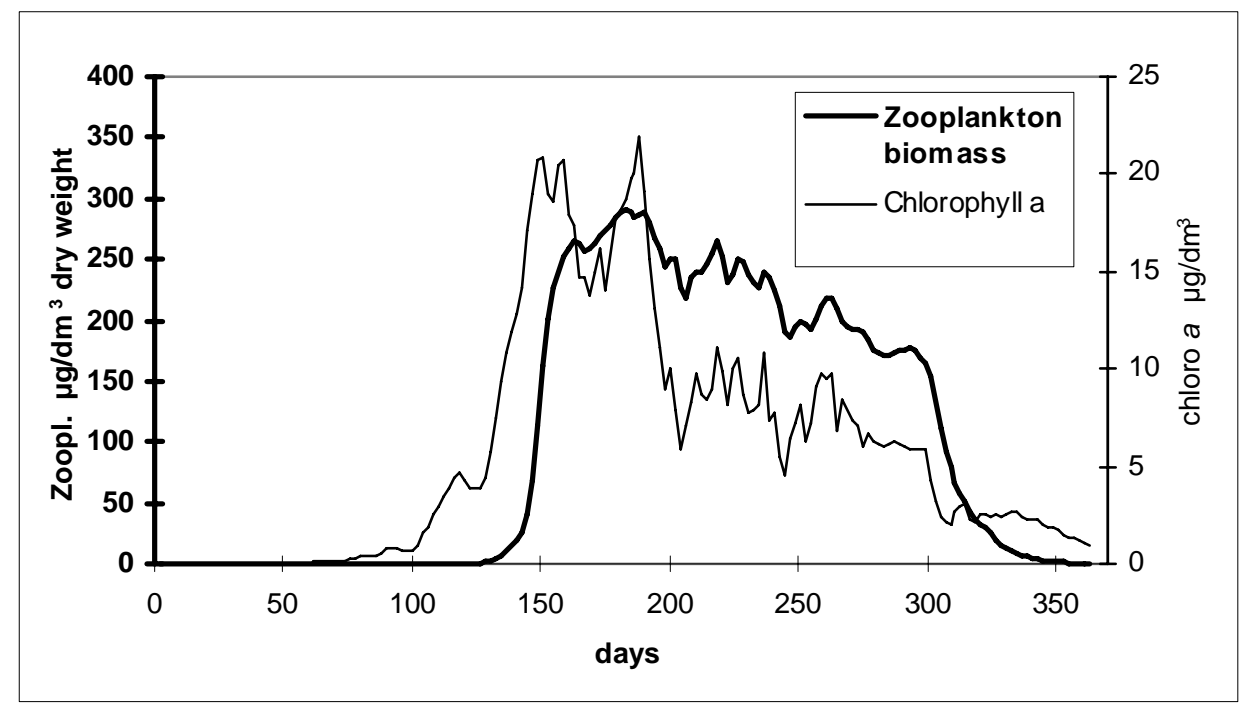


Fig 8 : Time series of measured and simulated particulate exchangeable phosphate concentrations in suspended matter and in sediments for the years 1992 and 1994 (boxes No 1, 3 and 4)

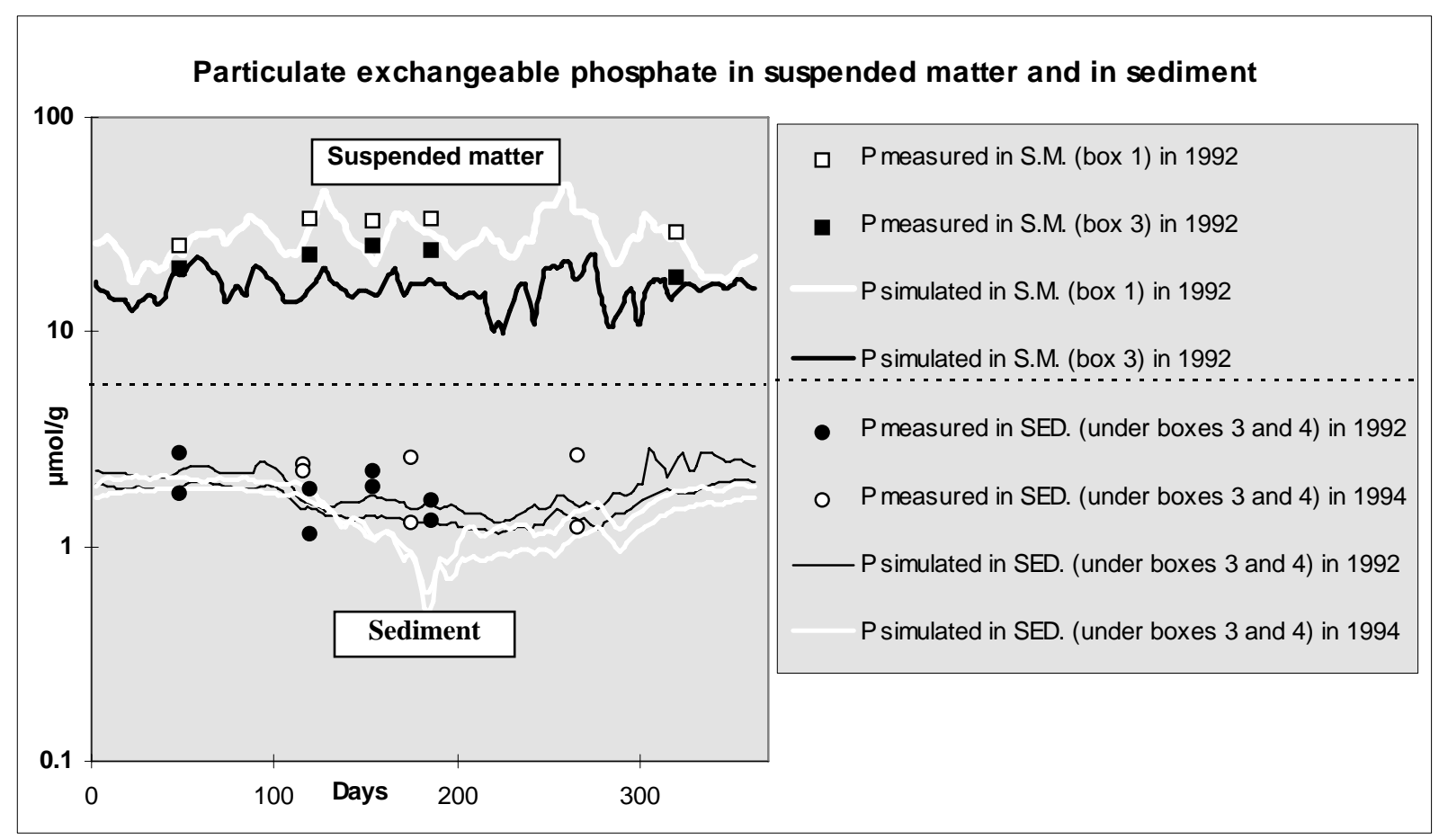

Fig 9: Comparison between measured and simulated particulate exchangeable phosphate concentrations in sediments of the Bay of Seine in February 1992

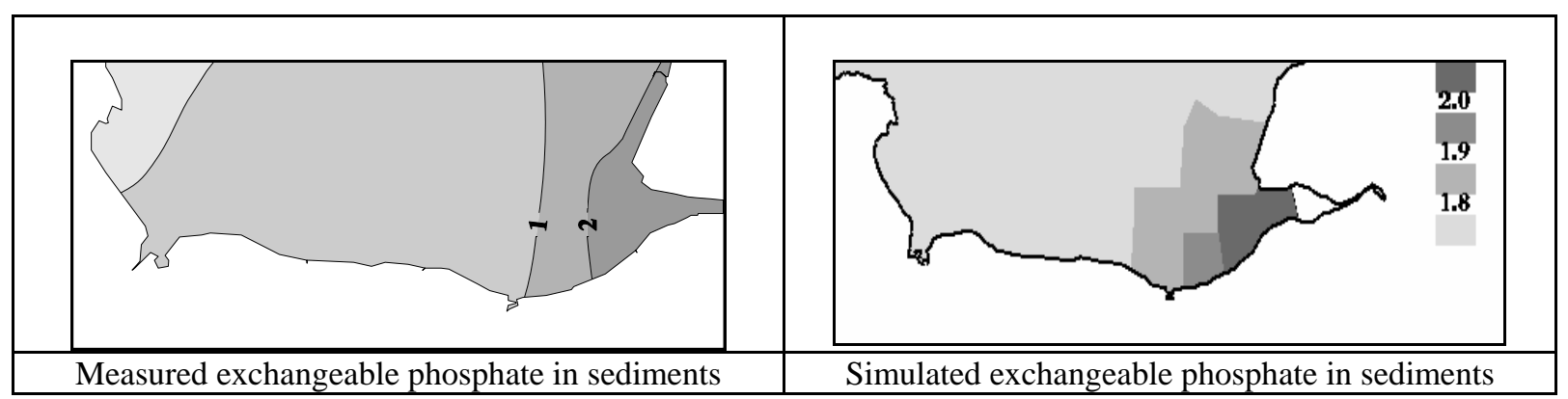


Fig 10: Time series of measured and simulated detrital organic phosphorus concentrations in suspended matter and in sediments for the year 1992 (box No 3)

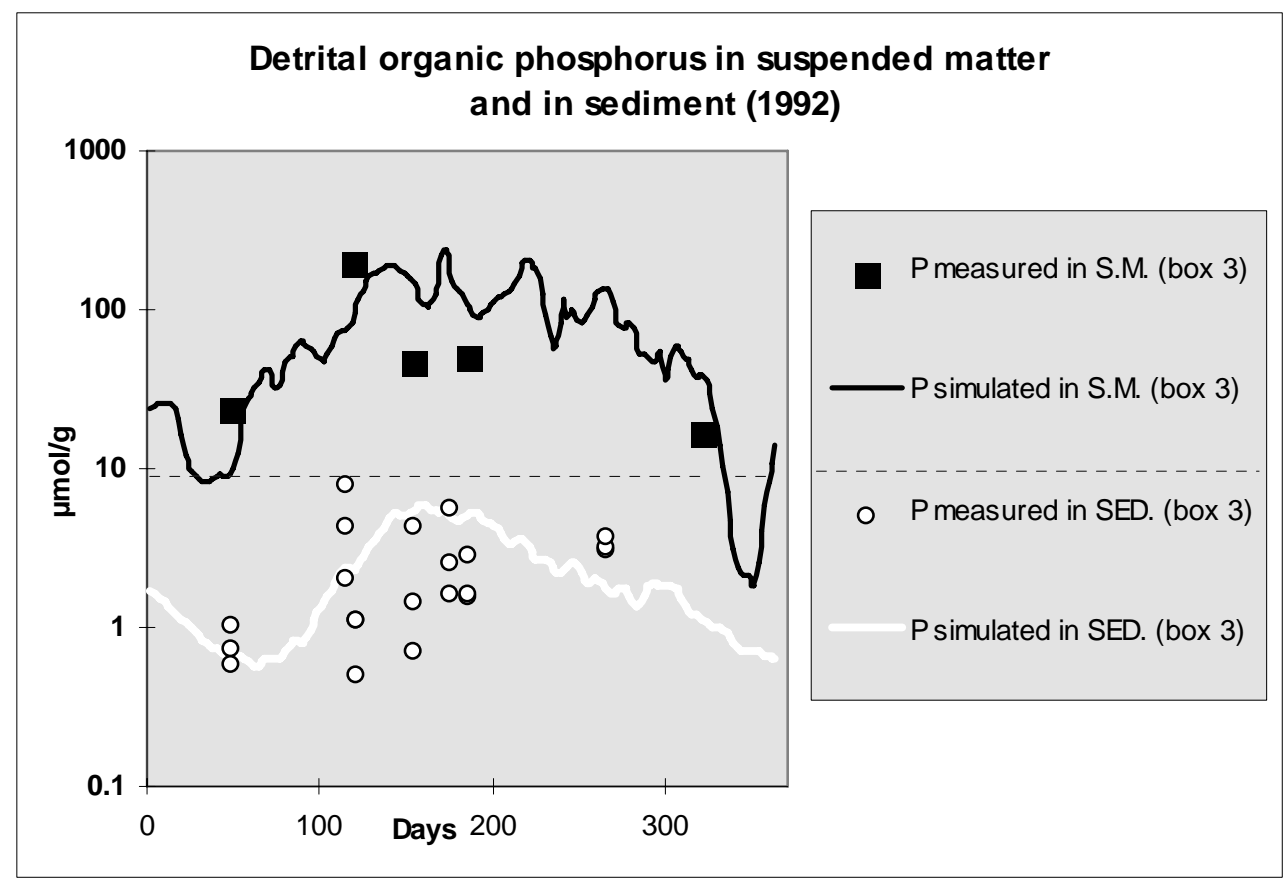


Fig 11 : Calculated nutrient limitation for diatoms and flagellates in the plume area and in the offshore waters in 1995

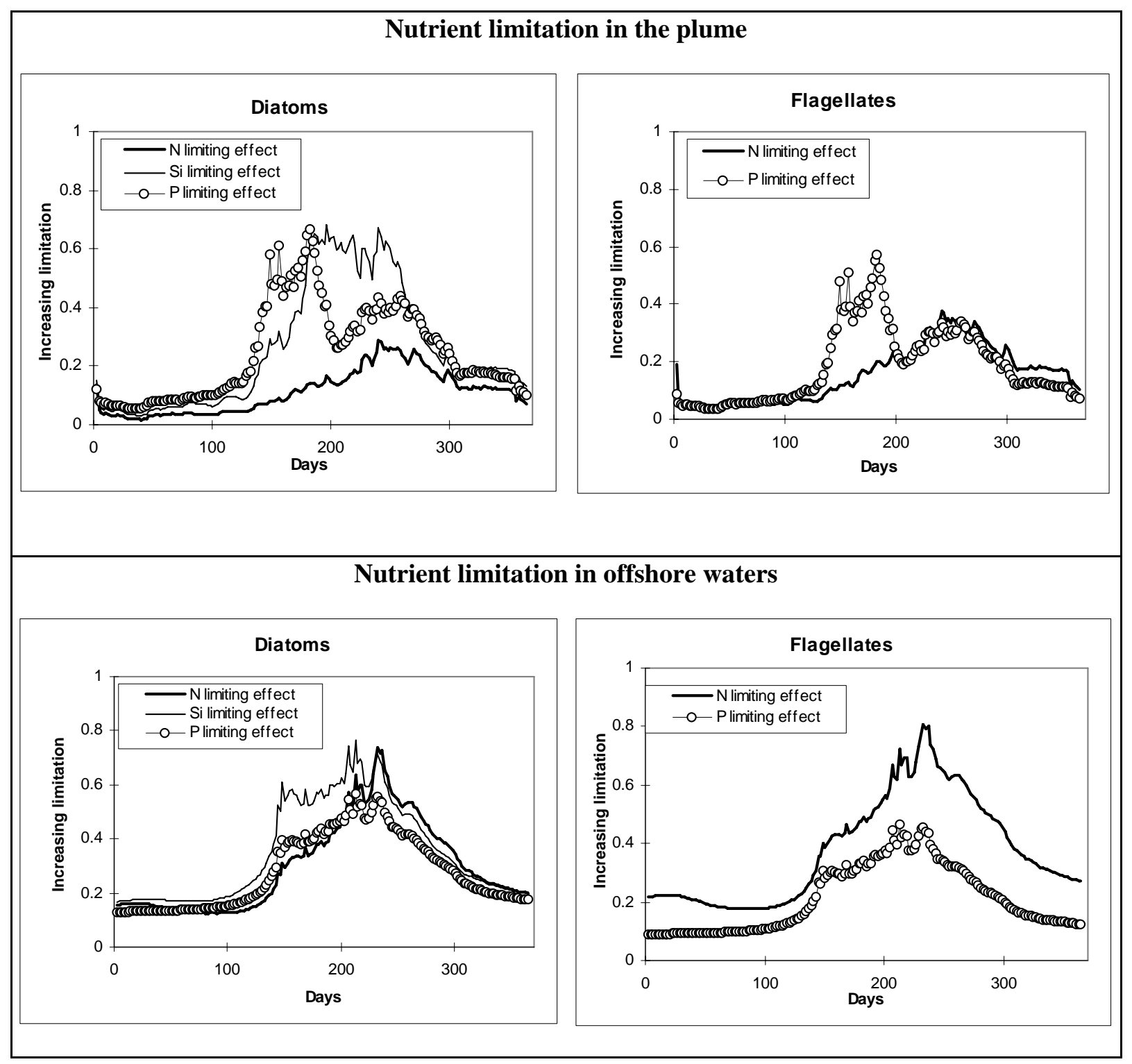

Fig 12 : Calculated nutrient limitation for diatoms in the plume area in 1978 and 1995

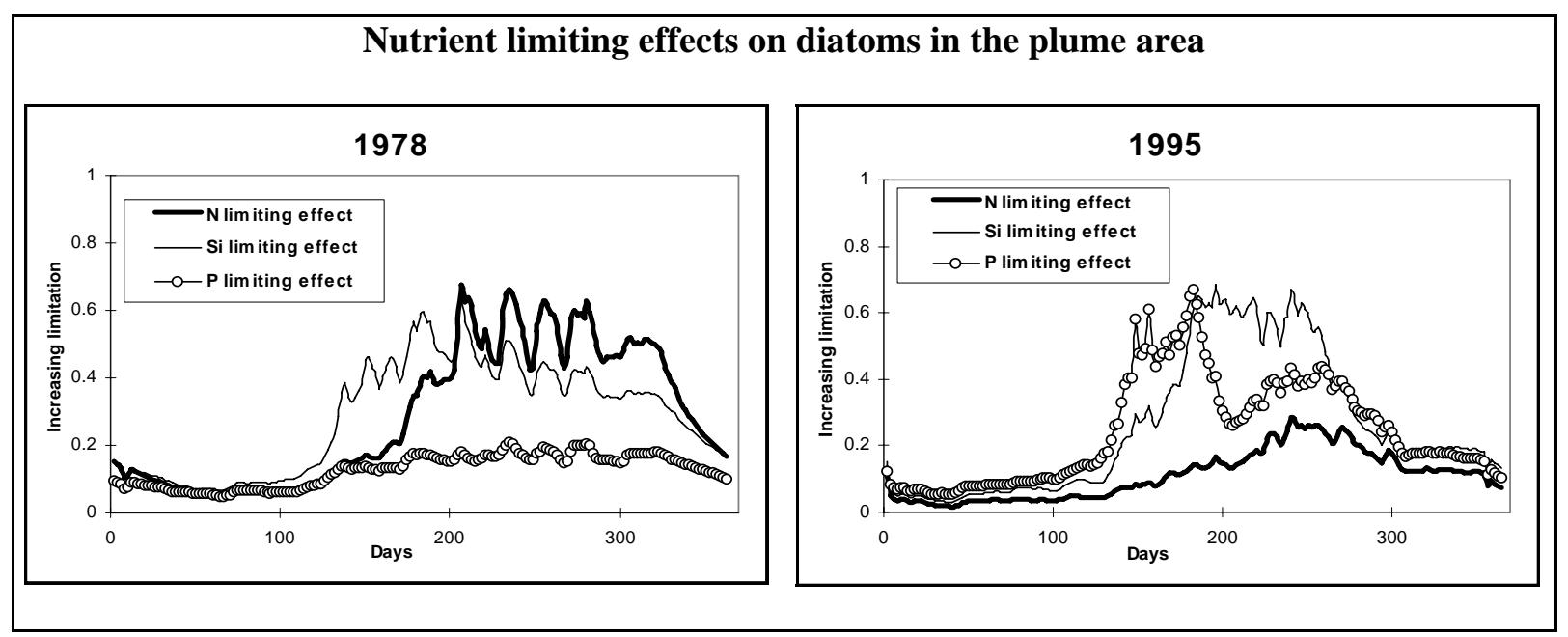

